\title{
Hybrid fuel cell and battery propulsion system modelling and multi-objective optimisation for a coastal ferry
}

\author{
Peng Wu*, Richard Bucknall \\ Marine Research Group, Department of Mechanical Engineering, University College London, London \\ WC1E $7 J E, U K$
}

\begin{abstract}
Efforts from all sectors of society including the shipping industry are needed to limit the overall global temperature rise to within $2{ }^{\circ} \mathrm{C}$ of pre-industrial levels by 2050 . The hybridisation of Proton Exchange Membrane Fuel Cells (PEMFC) and Lithium-ion batteries for coastal ship propulsion systems may potentially offer beneficial emission performance. However, such hybrid systems are constrained by power and energy density limitations, lifetime; and costs as well as life-cycle emissions of alternative fuel/energy. There is a lack of holistic design methodology dealing with these uncertainties in the literature. This paper proposes a holistic design methodology for coastal hybrid ships based upon a developed model. The power source sizing problem is solved using constrained mixed-integer multi-objective optimisation in the external layer. The global optimum energy management strategies for an averaged operating profile are obtained from deterministic dynamic programming in the inner layer, while considering power source degradations in the sizing algorithm. The proposed methodology was applied to a coastal ferry to investigate the feasibility and benefit potential of adopting the hybrid PEMFC and battery propulsion system in Matlab. The case studies indicate that the proposed propulsion system can achieve at least a $65 \%$ life-cycle greenhouse gas reduction for the considered two cases.
\end{abstract}

Keywords:

coastal ferry, hybrid propulsion system design, multi-objective optimisation

*Corresponding author
$\quad$ Email addresses: peng.wu.14@ucl.ac.uk (Peng Wu), r.bucknall@ucl.ac.uk (Richard Bucknall) 


\section{Nomenclature}

\begin{tabular}{|c|c|c|c|}
\hline Symbol & Description & Symbol & Description \\
\hline Roman symbols & & $T$ & Temperature, $\mathrm{K}$ \\
\hline$A_{m}$ & Active area of membrane electrode assembly, $\mathrm{cm}^{2}$ & $t_{m}$ & Membrane thickness, m \\
\hline$a$ & Water activity & $V_{k}$ & Voltage for fuel cell system, $\mathrm{V}$ \\
\hline$C R$ & Inlet air compression ratio & $V_{D}$ & System volume for system model, $\mathrm{m}^{3}$ \\
\hline C & Battery C-rate & $V_{x}$ & Alternative system volume, $\mathrm{m}^{3}$ \\
\hline$C_{1}$ & Battery cell model capacitance, F & $W_{x}$ & Alternative system weight, $\mathrm{kg}$ \\
\hline$c_{p}$ & Air specific heat capacity, $\mathrm{kJ} \mathrm{kg}^{-1} \mathrm{~K}^{-1}$ & $W_{D}$ & Original diesel system weight, $\mathrm{kg}$ \\
\hline$c_{1}$ & Concentration overpotential coefficient & $Z$ & Sizing decision variable vector \\
\hline$D$ & Degradation rate & Greek symbols & \\
\hline$F$ & Faraday constant, $96485 \mathrm{C} \mathrm{mol}^{-1}$ & $\beta$ & Concentration overpotential coefficient \\
\hline$F(Z)$ & Sizing objective function vector & $\gamma_{a}$ & Air specific heat ratio \\
\hline$f_{k}$ & Sizing objective function & $\gamma_{m}$ & Electrode surface roughness factor \\
\hline G & Gibbs free energy of activation & $\delta$ & Degradation function \\
\hline$I$ & Current & $\Delta t$ & Time step, s \\
\hline$i$ & Current density, $\mathrm{Acm}^{-2}$ & $\eta_{c}$ & Air compressor efficiency \\
\hline$i_{0}^{k}$ & Exchange current density, $\mathrm{Acm}^{-2}$ & $\eta_{m}$ & Air compressor motor efficiency \\
\hline$i_{k}$ & Battery cell model current, A & $\eta_{f c}$ & Fuel cell stack net efficiency \\
\hline$i_{L}$ & Limiting current density, $\mathrm{Acm}^{-2}$ & $\eta$ & Efficiency \\
\hline$I_{f c}$ & Fuel cell stack current, A & $\lambda$ & Degree of humidification \\
\hline$k_{1}$ & Fuel cell balancing of plant power coefficient & $\sigma_{k}$ & Price, USD \\
\hline$L H V$ & Hydrogen lower heating value, $\mathrm{kJ} \mathrm{kg}^{-1}$ & $\sigma_{m}$ & Fuel cell membrane conductivity, $\mathrm{S} \mathrm{m}^{-1}$ \\
\hline$\dot{m}$ & Mass flow rate, $\mathrm{kg} \mathrm{s}^{-1}$ & $v_{k}$ & GWP, $\mathrm{kg} \mathrm{CO}_{2} \mathrm{~kg}^{-1}$ \\
\hline$m_{1}$ & Number of fuel cell strings connected in parallel & $\psi_{f c}$ & Fuel cell specific $\mathrm{H}_{2}$ consumption, $\mathrm{kgkWh}^{-1}$ \\
\hline$m_{2}$ & Number of fuel cells connected in series & Abbreviations & \\
\hline$n_{1}$ & Number of battery strings connected in parallel & $\mathrm{AC}$ & Alternating current \\
\hline$n_{2}$ & Number of battery cells connected in series & $\mathrm{DC}$ & Direct current \\
\hline$n$ & Molar flow rate, $\mathrm{mols}^{-1}$ & DDP & Deterministic dynamic programming \\
\hline$P$ & Power in system model, $\mathrm{kW}$ & EMS & Energy management strategy \\
\hline$P$ & Pressure in fuel cell model, $\mathrm{Pa}$ & GHG & Greenhouse gas \\
\hline$p$ & Partial pressure & GWP & Global warming potential \\
\hline$R$ & Universal gas constant & LNG & Liquefied natural gas \\
\hline$R_{k}$ & Battery model resistance, $\Omega$ & PEMFC & Proton exchange membrane fuel cell \\
\hline $\operatorname{sp} A$ & Shore power availability & $\mathrm{SOC}$ & State of charge \\
\hline$S O C$ & Battery state of charge & & \\
\hline
\end{tabular}




\section{Introduction}

The global commercial shipping fleet emitted $2.2 \%$ of global anthropogenic Greenhouse Gases (GHGs) in 2012 (International Maritime Organization, 2014). By 2050, the maritime transport segment needs to reduce its total annual GHG emissions by $50 \%$ compared to 2008 to be in line with the global GHG reduction target to limit the global temperature rise to no more than $2{ }^{\circ} \mathrm{C}$ above pre-industrial level (Vergara et al., 2012; Cames et al., 2015). On the other hand, almost $15 \%$ of total global anthropogenic $\mathrm{NO}_{\mathrm{x}}$ emissions and $4-9 \%$ of $\mathrm{SO}_{\mathrm{x}}$ emissions are from shipping which is a significant and increasing source of air pollutants (Endresen et al., 2003; Eyring et al., 2010; Viana et al., 2014). Nearly 70\% of these emissions are estimated to occur within $400 \mathrm{~km}$ of coastlines, which has a potential influence on air quality in coastal areas where $45 \%$ of the world's population resides (Corbett et al., 1999; Viana et al., 2014; Kay and Alder, 2017). There is a necessity to cut down emissions from ships, especially those operate in coastal waters.

Marine diesel engines operating with heavy fuel oil or marine diesel oil are not a viable powering solution for the shipping industry in terms of the required reduction in GHG and pollutants (Deniz and Zincir, 2016). Various efforts have been made to improve the existing diesel engine based technologies, e.g. using Liquefied Natural Gas (LNG) in dual-fuel or gas engines (Thomson et al., 2015). Though the $\mathrm{NO}_{\mathrm{x}}, \mathrm{SO}_{\mathrm{x}}$ and particulate matter emissions can be reduced significantly with LNG, the GHG saving offered by LNG is limited to no more than 21\%, and methane slips could potentially cancel out the benefit (Brynolf et al., 2014; Thomson et al., 2015; Ekanem Attah and Bucknall, 2015). Ships operating within Emissions Control Areas have adopted exhaust gas treatment devices which could potentially lead to the GHG emission performance being even worse as a consequence of the requirement for additional power and the negative impacts on engine efficiency (Verschaeren et al., 2014; Di Natale and Carotenuto, 2015; Boscarato et al., 2015).

Proton Exchange Membrane Fuel Cells (PEMFC) operating on $\mathrm{H}_{2}$ has gone through rapid development in recent decades with improving performance and reducing cost and has been adopted by parallel industries such as road transport (Alaswad et al., 2016; Dicks and 
Rand, 2018). There has been an increasing interest in utilising PEMFC for ship applications (Van Biert et al., 2016; Choi et al., 2016; Sasank et al., 2016; de Troya et al., 2016). Compared to other fuel cell types such as the solid oxide fuel cell or molten carbonate fuel cell, PEMFC offers better power density and transient performance but a lower efficiency and less fuel flexibility (Sharaf and Orhan, 2014). When used in transport applications, PEMFC is typically used with batteries or supercapacitors to provide better overall efficiency and capability for managing power transients.

Lithium batteries are a rapidly evolving technology recognised as having great potential for utilising renewable energy and improving the performance of existing powering solutions (Luo et al., 2015; Hannan et al., 2017). Batteries can be used as stand-alone or in hybrid configurations in ship propulsion systems. When used in hybrid configuration, batteries can optimise the loadings on other power sources (e.g. fuel cells or internal combustion engines). Ovrum and Bergh (2015) reported that 30\% fuel reduction could be achieved with regenerative energy recovered from the ship crane operations. In configurations without regeneration, much less fuel saving can be expected, depending on the configuration and power profiles. $15 \%$ fuel saving is reported in a case of a non-regenerative hybrid ship (Stefanatos et al., 2015). When only a battery is used, the shipboard system becomes zeroemission, but the life-cycle emission performance depends on the energy source of the shore supplied electricity. Currently battery technologies are still constrained by limited energy densities, even though the world's largest battery package in ship applications has reached a capacity of 6.1 MW h (Larcher and Tarascon, 2015; Corvus, 2019).

Methodologies for dealing with the solution of the optimal sizing problem for shipboard hybrid propulsion systems are rare in the literature. Kim and Peng (2007) addressed the importance of combining power source design and EMS for hybrid fuel cell/battery road vehicles, in which a near optimal "pseudo-Stochastic Dynamic Programming" EMS was developed for a standard driving cycle. Xu et al. (2015) proposed a two-loop multi-objective power source sizing methodology with EMS solved by dynamic programming in the inner loop, looking into the trade-off problem between fuel consumption and battery degradation of a fuel cell city bus. Xie et al. (2018) presented a multi-objective optimisation methodology 
for retrofitting a mid-scale aircraft with batteries. Bassam (2017) proposed a dimensioning methodology for the non-plug in hybrid PEMFC and battery propulsion system using an exhaustive search of the battery module and fuel cell stack numbers with several time domain energy management strategies considered. However, through life emissions of the energy sources were not considered in this study.

It would appear that coastal ships operating on short routes at modest speed may potentially benefit from hybrid propulsion systems with a mix of PEMFC and batteries, utilising clean $\mathrm{H}_{2}$ energy and shore-generated electricity (McConnell, 2010; de Troya et al., 2016; Van Biert et al., 2016). However, the design of such hybrid propulsion systems must consider a series of variables to achieve an overall optimal design. As shown in Figure 1, the alternative system has to provide sufficient and reliable power, without using too large a volume and mass margins from the propulsion plant. Moreover, the alternative system needs to be more environmentally friendly and commercially competitive.

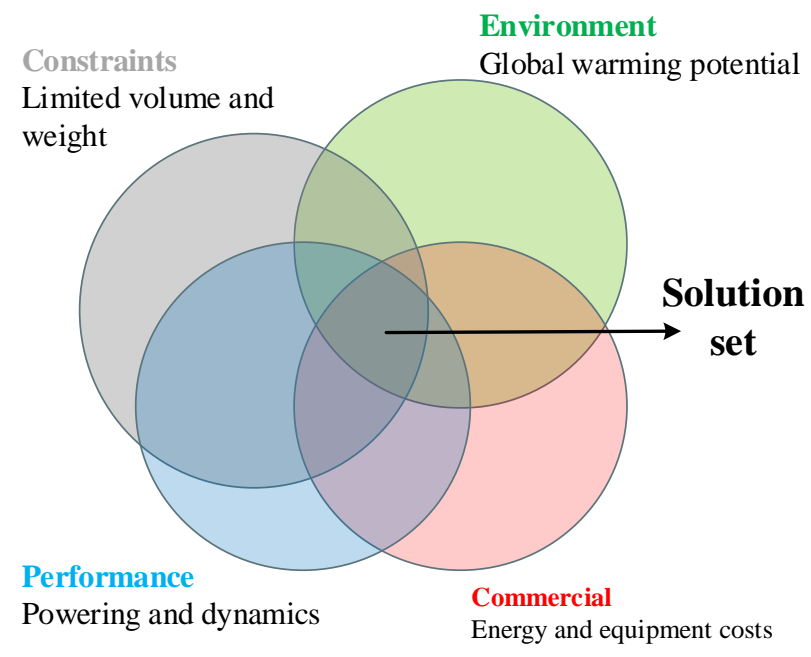

Figure 1: The complexity of alternative propulsion system design.

Although $\mathrm{H}_{2}$ appears as a clean fuel when the scope is only limited to the propulsion system, the $\mathrm{H}_{2}$ production processes could be carbon intensive (Acar and Dincer, 2014). Also, the power generation process that provides the energy for $\mathrm{H}_{2}$ production and battery charging would have a certain carbon intensity and this intensity would vary depending 
upon location. For example, in 2016, the average GHG emission of grid power in the UK was $281 \mathrm{~g} \mathrm{CO}_{2} \mathrm{kWh}^{-1}$, while for Denmark it was $166 \mathrm{~g} \mathrm{CO}_{2} \mathrm{kWh}^{-1}$ (European Environment Agency, 2017). Other factors including power source power/energy densities, degradation characteristics, energy properties and operational requirements can vary from place to place and significantly influence the design of such a hybrid propulsion system. A holistic design methodology can be used to achieve an optimal alternative propulsion system design.

In this paper, an improved multi-objective power source design methodology and a propulsion system model for plug-in hybrid PEMFC/battery propulsion systems with access to hydrogen bunkering and battery charging facilities are proposed, extending the authors' previous work (Wu and Bucknall, 2018). In the authors' previous work, the optimisation scheme was designed to provide the power ratings and battery capacity with a simplified system model. The current work has improved the author's precious work with models calibrated by experimental results, and the optimisation scheme has been improved to output detailed sizing combinations. The proposed design methodology can be used to guide the shipboard hybrid plug-in fuel cell and battery propulsion system design in different regions with variable energy properties. Two case studies, i.e. for the Denmark and UK scenarios, are provided to investigate the influences of energy life-cycle properties on the design of such hybrid systems.

\section{System model}

\subsection{Assumptions}

When using the proposed sizing methodology based on the system model, the following assumptions apply and are deemed acceptable for the power source sizing optimisation purpose.

- There always exists suitable power converters that can match the efficiency curves adopted in this study for the power source sizes considered.

- Shore power is instantly available when the ship arrives at the ports; in reality it requires extra time to establish the electrical connections which would prolong the 
required port time. Nevertheless, note that automated charging solutions using industrial robots with minimised connection time is commercially available (ABB, 2018).

- Energy available on both end of the case ship route has identical properties considering the case ship only operate domestically in Denmark with a voyage duration of $1 \mathrm{~h}$.

\subsection{System overview}

To achieve optimal design of a plug-in hybrid PEMFC and battery propulsion system for coastal ships, a quasi-steady state model with PEMFC and lithium batteries that can be adjusted to scale has been developed. Figure 2 presents the system schematic of a plugin hybrid PEMFC battery propulsion system. Such a layout is designed for coastal ships sailing on short routes with access to battery charging and $\mathrm{H}_{2}$ replenishing infrastructure. The power distribution system is DC based to better accommodate the fuel cells and energy storage system. Although there are still practical challenges of implementing such a DC power system, it directly matches the proposed power sources better than an AC distribution system (Hansen and Wendt, 2015). The power converters for the fuel cell stack, battery and shore electricity are unidirectional DC/DC, bidirectional DC/DC and unidirectional AC/DC, respectively. The fuel cells operating with on-board stored $\mathrm{H}_{2}$ are controlled by the energy management system. Note that shore electricity is only available when the ship is berthed. 


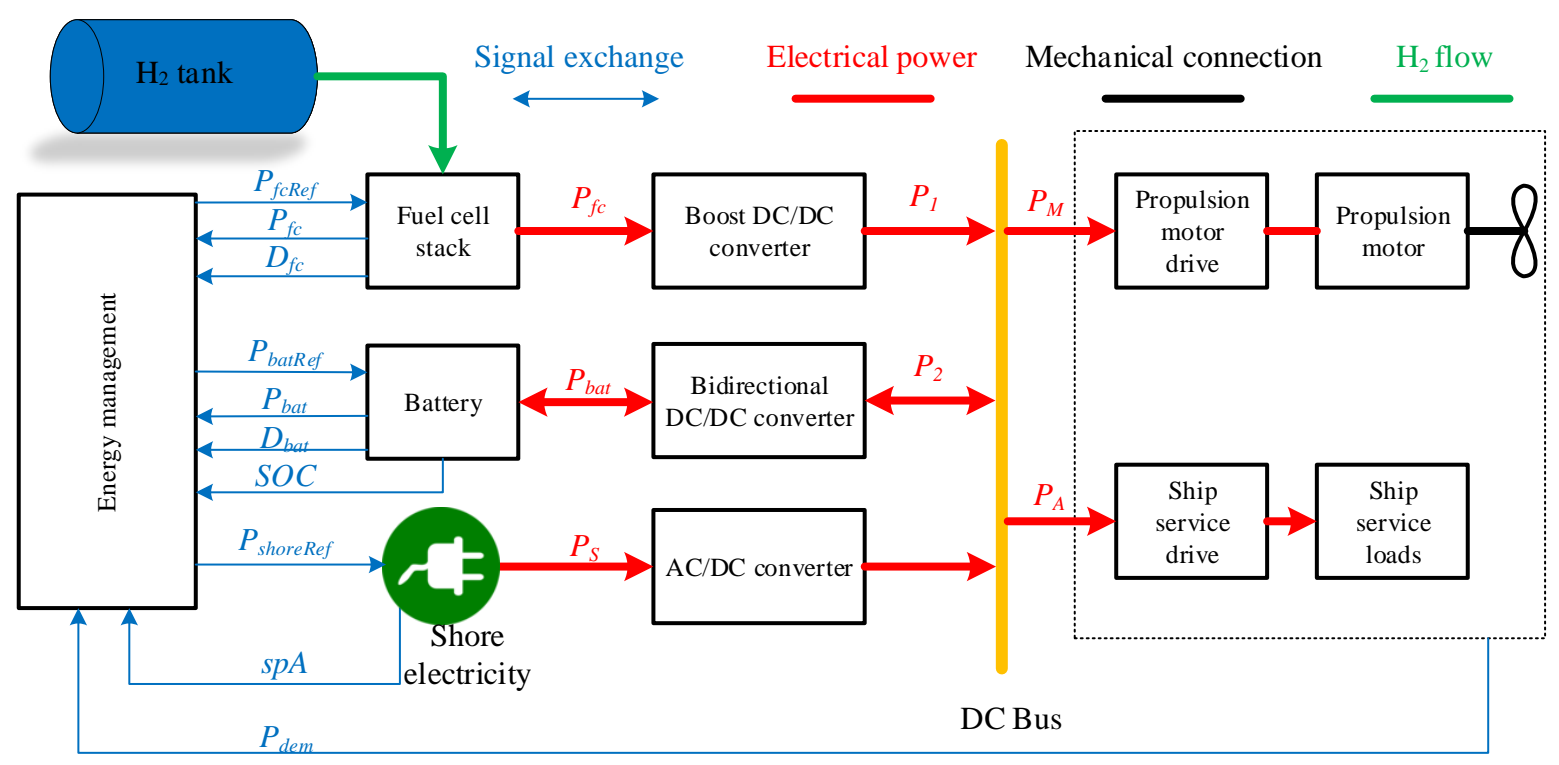

Figure 2: Hybrid propulsion system schematic.

Two main modes of operation are envisaged to occur during the ship's routine operation: sailing and port modes. In sailing mode, either cruising or manoeuvring, the battery works as an energy buffer to optimise the fuel cell loadings and reduce power transients at the PEMFC. Note that the battery can be either charged or discharge in sailing mode. When the ship is berthed, i.e. in port mode, the shore connection charges the battery and powers the ship's electrical loads, while the PEMFC is switched off line or shut down.

The energy management system manages the power split between the power sources by monitoring of power demand, fuel cell power level, battery State of Charge (SOC) and shore power availability, then determines fuel cell power change for the next time step. For each 
time step, the power supplied by the power sources has to satisfy:

$$
\begin{aligned}
& P_{1}+P_{2}+P_{s}=P_{d e m} \\
& P_{1}=P_{f c} \eta_{1} \\
& P_{f c}= \begin{cases}\geq 0, & \text { sailing mode } \\
=0, & \text { port mode }\end{cases} \\
& P_{s}= \begin{cases}=0, & \text { sailing mode } \\
\geq 0, & \text { port mode }\end{cases} \\
& P_{2}= \begin{cases}P_{b a t} \eta_{2}, & P_{b a t} \geq 0 \text { for battery discharging or idling } \\
P_{b a t} / \eta_{2}, & P_{b a t}<0 \text { for battery charging }\end{cases}
\end{aligned}
$$

where $P_{1}$ and $P_{2}$ are the fuel cell and battery power after the power converters respectively; $P_{f c}$ and $P_{b a t}$ are fuel cell stack power output and battery power output respectively; $P_{d e m}$ is the ship's lumped loads (including propulsive and auxiliary); note that $P_{f c}$ is determined by the EMS in sailing mode and the fuel cell will not be providing any power to the system when the ship is on shore supply. $\eta_{1}$ and $\eta_{2}$ are the fuel cell and battery power converter efficiencies respectively.

\subsection{Power converter efficiency model}

The power converter efficiency models output energy efficiency with input of per unit power to the converters. Note that the converter efficiency models are representative of achievable characteristics, and be easily updated with real data when actual converter features are available for actual engineering applications. Such an approach is valid, and has been widely adopted in similar studies (Hu et al., 2015; Kalikatzarakis et al., 2018). As shown in Figure 3a, the power conversion efficiencies are plotted against the percentage power output for each of the conversion modes. These efficiency models are based upon experimental data (Kanstad et al., 2019; Tseng et al., 2016). The maximum error of these fitted efficiency curves is $3 \%$, which occurs at the $20 \%$ loading condition (3b). In high load regions, the efficiency errors are below $1 \%$. 


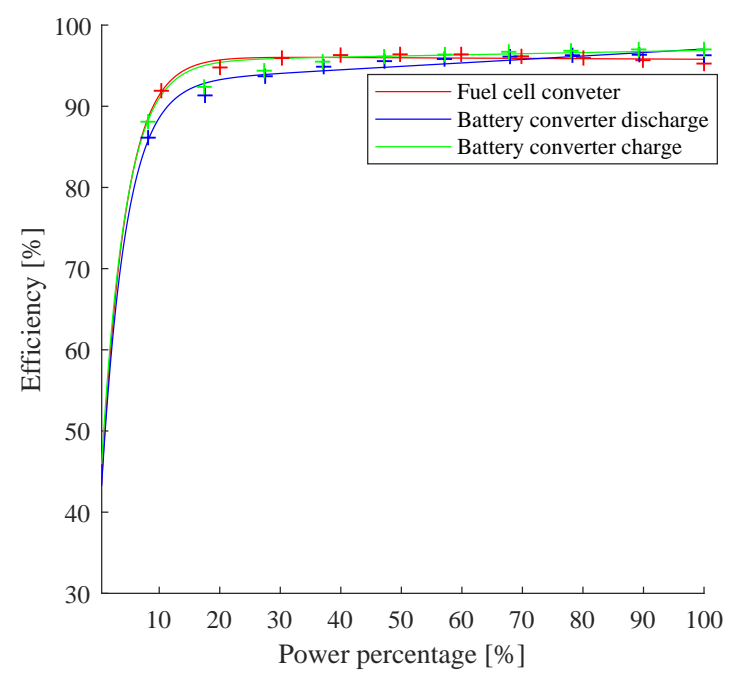

(a)

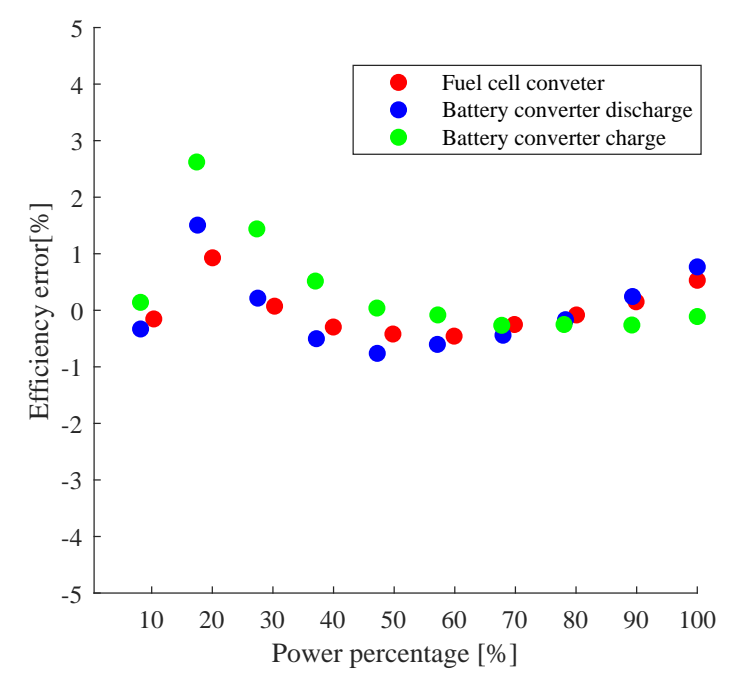

(b)

Figure 3: Power converter efficiency: (a) power converter efficiency curves fitted from experimental results and (b) errors of fitted efficiency curves compared to experimental data from (Kanstad et al., 2019; Tseng et al., 2016).

\subsection{PEMFC fuel cell model}

To obtain fuel cell system specific hydrogen consumption and fuel cell degradation rates under different operating conditions, a system level PEMFC model has been developed and calibrated. Figure 4 presents the schematic of the PEMFC single cell and stack system, including ancillary components such as air compressor (Pukrushpan, 2003; Dicks and Rand, 2018). Note that the focus of this study is on system level optimisation instead of dynamic performance. Therefore the cell electrical double layer effects were not included here, readers are referred to studies such as (Liang et al., 2018) for modelling of these effects. The fuel cell stack model considers auxiliary power consumptions. Individual cell outputs are connected in series and parallel to form the stack output. 


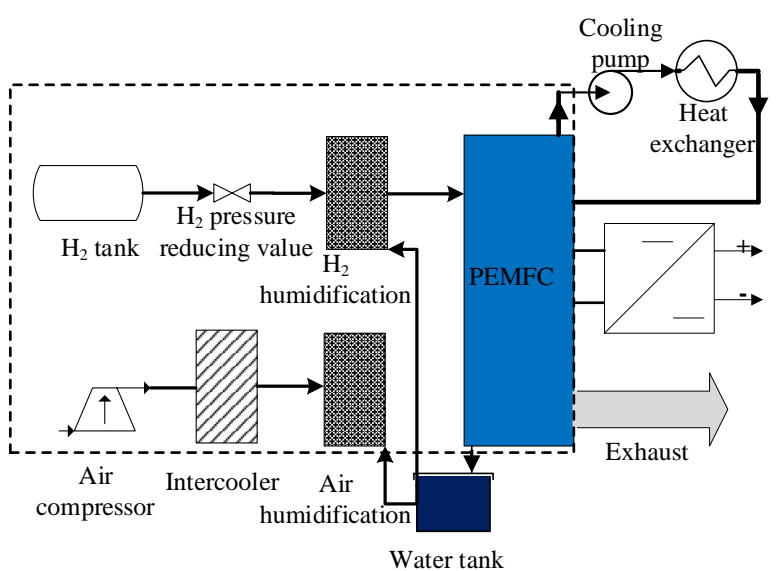

(a)

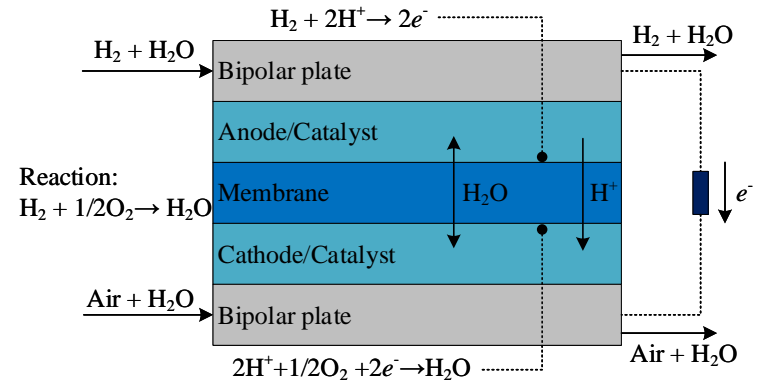

(b)

Figure 4: Fuel cell schematic: (a) PEMFC system and (b) single cell.

\subsubsection{Single cell model}

The single cell model considers three overpotentials, i.e. ohmic overpotential $V_{\text {ohm }}$, activation overpotential $V_{a c t}$ and convection overpotential $V_{c o n}$. Due to the three overpotentials, the single cell output voltage $V_{\text {cell }}$ varies at different current densities (corresponding to different loadings). The single cell governing equations are described in Appendix (Table 7). The PEMFC model is calibrated using the results acquired from (Yan et al., 2006). The molar flow rates of $\mathrm{O}_{2}, \mathrm{H}_{2}$ and $\mathrm{H}_{2}$ O, i.e. $n_{\mathrm{O}_{2}}, n_{\mathrm{H}_{2}}$ and $n_{\mathrm{H}_{2} \mathrm{O}}^{k}$ were calculated using the method provided in (Abdin et al., 2016). Model adjustable parameters such as $\beta, i_{L}, \gamma_{m}, i_{0}^{R e f}$ and $\alpha$ are estimated by minimising the difference between model voltage output and experimental results. As the identification of model parameters is not the focus of this study, the optimisation process is not presented here. Once these parameters are calibrated, the model is verified by running the model in other operating states.

\subsubsection{PEMFC stack model}

By connecting the individual fuel cell outputs in series and parallel, the PEMFC stack model is formulated. It is assumed that all the cells within the stack perform uniformly. The total electrical power output of the stack is calculated by:

$$
P_{f c}=V_{f c} I_{f c}-P_{c o m}-P_{a u x}
$$


where $V_{f c}$ and $I_{f c}$ are fuel cell stack voltage and current output respectively, and $V_{f c}=$ $n_{1} V_{\text {cell }}, I_{f c}=m_{1} I_{\text {cell }}=m_{1} i A_{m}$ ( $m_{1}$ is number of strings in parallel, $n_{1}$ is number of cells in series, $A_{m}$ is active area of membrane electrode assembly). $P_{\text {com }}$ is the power consumed the by air compressor (Dicks and Rand, 2018):

$$
P_{\text {com }}=\frac{1}{\eta_{c} \eta_{m}} \dot{m}_{a i r} c_{p} T\left[C R^{\left(\frac{\gamma_{a}-1}{\gamma_{a}}\right)}-1\right]
$$

where $\eta_{c}$ is the air compressor efficiency, obtained from (Dicks and Rand, 2018) and normalised with respect to fuel cell loading. $\eta_{m}$ is the compressor motor efficiency, and it is assigned a constant value of 0.96 in this study. $c_{p}=1004 \mathrm{~J} \mathrm{~kg}^{-1} \mathrm{~K}^{-1}$ is the inlet air specific heat. $C R$ is the cathode air compression ratio which increases along the compressor operating line when fuel cell load level increases. $\gamma_{a}$ is the air specific heat ratio. $P_{a f c}$ is balancing of plant power, and is a linear function of fuel cell power (Kim and Peng, 2007):

$$
P_{a f c}=k_{1} P_{f c}+c_{2}
$$

where $k_{1}$ and $c_{2}$ are constant coefficients. The fuel cell stack net efficiency is calculated by:

$$
\eta_{f c}=\frac{P_{f c}}{\dot{m}_{H_{2}} L H V} \times 100 \%
$$

where $L H V$ is the Lower Heating Value of $\mathrm{H}_{2}, \dot{m}_{H_{2}}$ is hydrogen mass flow rate which can be calculated from cell $\mathrm{H}_{2}$ molar flow rate $n_{H_{2}}$, molar mass and total cell number.

Figure 5a shows the single cell power at different current densities and corresponding power consumed by the air compressor and other auxiliary loads. The fuel cell stack net efficiency and specific $\mathrm{H}_{2}$ consumption across $0-100 \%$ fuel cell load are shown in 5b. The maximum fuel cell stack net efficiency is about $52 \%$; the net efficiency at full load is $36 \%$. 5c presents the fuel cell validation against experimental results. A good agreement between the model output and experimental results can be observed. The root-mean-squared error between the model output and experimental data is 0.031 (normalised root-mean-squared error is $3.5 \%)$. As shown in $5 \mathrm{~d}$, the fuel cells operating pressure increases along the compressor operating line with the increase of fuel cell load (Dicks and Rand, 2018). The fuel cell model outputs specific $\mathrm{H}_{2}$ consumption with the input of fuel cell power percentage. 


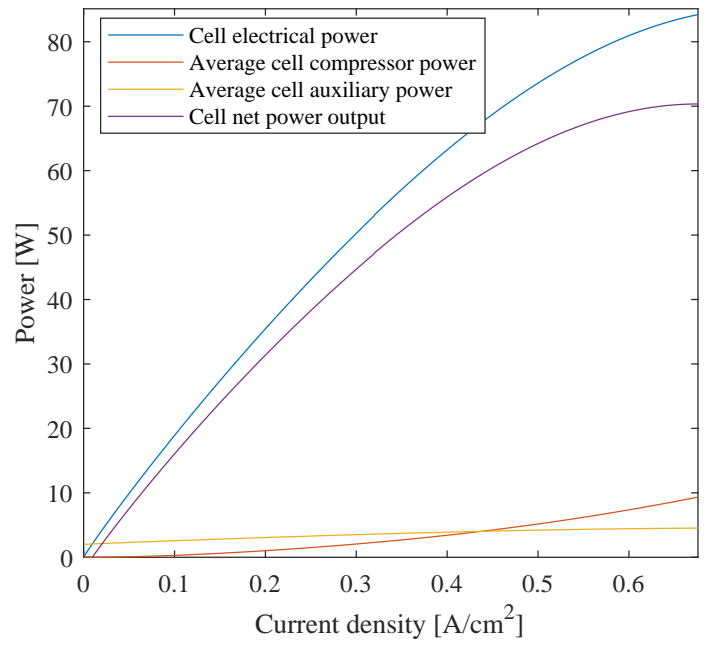

(a)

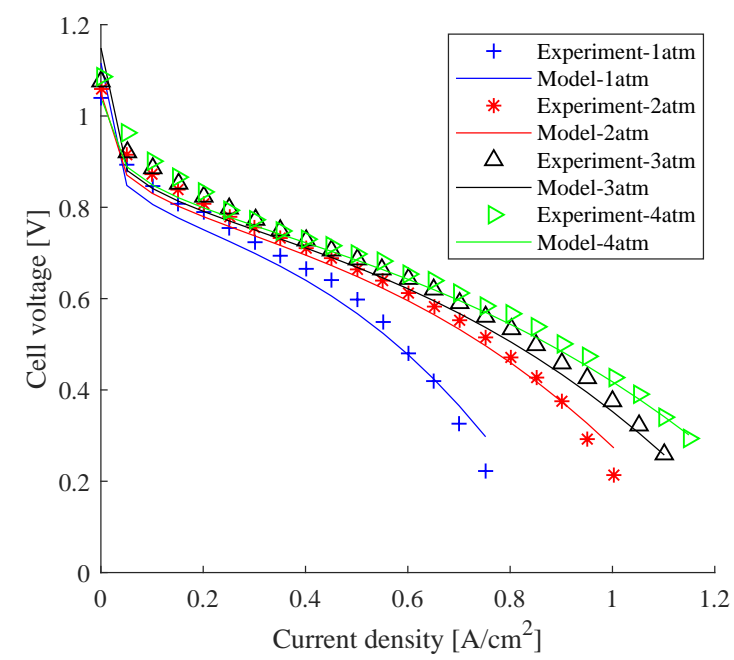

(c)

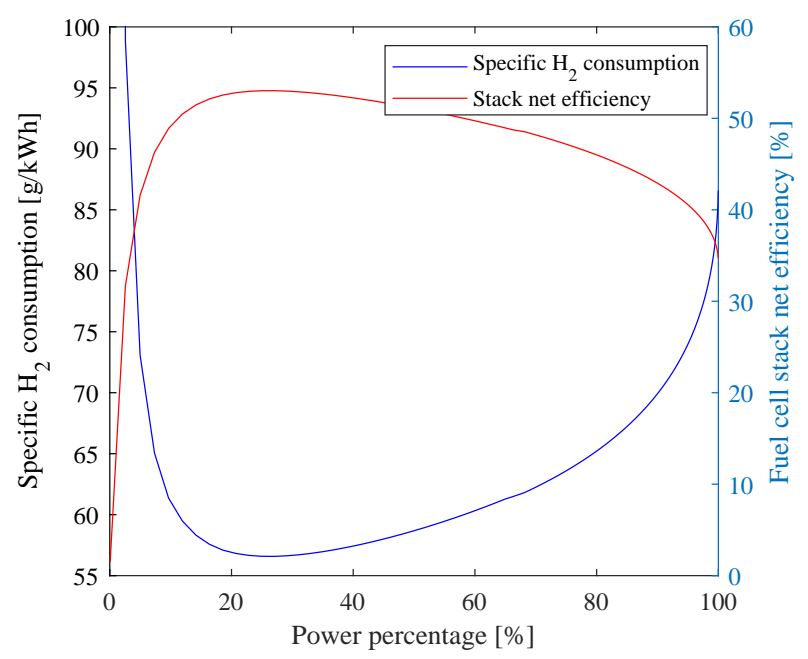

(b)

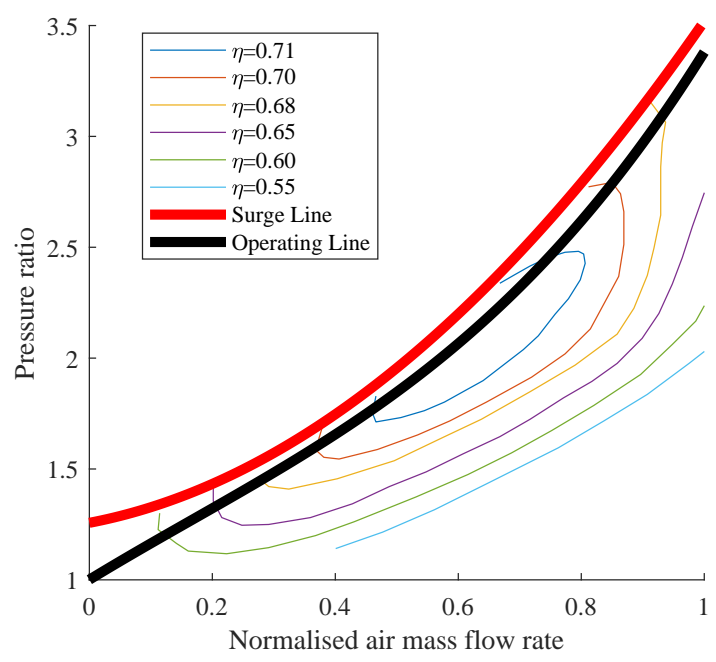

(d)

Figure 5: (a) Single cell power and auxiliary power consumption at different operating current densities, note that the compressor operates following the operating line in (d), the cell net power is cell electrical power subtracted by compressor and auxiliary loads and the net power output drops down rapidly after $0.68 \mathrm{~A} \mathrm{~cm}^{-2}$ hence regions beyond this point are not considered as useable region, (b) specific $\mathrm{H}_{2}$ consumption and net fuel cell stack efficiency in different fuel cell power fractions, highest efficiency appears around $20 \%$ power region, (c) validation of cell model in different pressures and (d) compressor map from (Dicks and Rand, 2018). 


\subsubsection{Degradation model}

Compared to marine diesel engines, PEMFCs generally have a much shorter operational lifetime; factors such as power transients, cycling and loading conditions can influence the rate of degradation. Considering the high production costs of PEMFC, it is necessary to include the degradation characteristics in both the design and operating phases of the ship to obtain the overall optimal cost performance. Table 1 describes the PEMFC single cell degradation rates used in this study (Fletcher et al., 2016; Chen et al., 2015). The cell degradation over one voyage is (Fletcher et al., 2016):

$$
D_{f c}=D_{\text {low }}+D_{\text {high }}+D_{\text {transient }}+D_{\text {cycle }}
$$

where $D_{\text {low }}, D_{\text {high }}, D_{\text {transient }}$ and $D_{\text {cycle }}$ are cell voltage degradation caused by low power operation, high power operation, power transient and start/stop cycling, respectively. These parameters may differ across different fuel cell types, depending on the design and actual operating parameters, and require calibration using experimental data before use.

Table 1: PEMFC cell degradation rates (Fletcher et al., 2016; Chen et al., 2015).

\begin{tabular}{ll}
\hline Operating condition & Degradation rate \\
\hline Low power (0-80\% rated power) & $10.17 \mu \mathrm{V} / \mathrm{h}$ \\
High power (> 80\% rated power) & $11.74 \mu \mathrm{V} / \mathrm{h}$ \\
Transient loading & $0.0441 \mu \mathrm{V} / \Delta \mathrm{kW}$ \\
Start/stop & $23.91 \mu \mathrm{V} /$ cycle \\
\hline
\end{tabular}

\subsection{Lithium-ion battery model}

To accurately represent battery performance across its capacity range, an equivalent circuit calibrated by experimental data from (Zheng et al., 2016) has been developed. Figure 6 shows the battery model equivalent circuit adopted in this study. The battery cells are connected in series and parallel to form the battery module (Hu et al., 2015):

$$
P_{b a t}=I_{B} V_{B}
$$


where $I_{B}, V_{B}$ are battery module current and voltage respectively. Note that $V_{B}=n_{2} V_{t}$, and $V_{t}$ is the battery cell terminal voltage, which is a function of battery cell open circuit voltage $V_{o c}(S O C)$ ( $V_{o c}$ is a function of battery SOC), $R_{0}, R_{1}$ and $C_{1}$ :

$$
\begin{gathered}
V_{t}=V_{o c}-i_{0} R_{0}-V_{c} \\
\dot{V}_{c}=-\frac{V_{c}}{R_{1} C_{1}}+\frac{i_{0}}{C_{1}}
\end{gathered}
$$

The open circuit voltage map $V_{o c}(S O C), R_{0}, R_{1}$ and $C_{1}$ were identified using least square algorithm with the dynamic stress test (DST) experiment data (@25 ${ }^{\circ} \mathrm{C}$ ) (Figure $7 \mathrm{a}$ ) and subsequently validated using urban driving schedule (UDS) cycle experiment results (Figure 7b), both sets of data were from (Zheng et al., 2016). As the influence of battery temperature is not the focus of this study, all these parameters were identified using experimental data $@ 25^{\circ} \mathrm{C}$. There was good agreement between the model output and experimental data. Over a period, the battery SOC change:

$$
S O C_{2}=S O C_{1}-\eta_{b} \int_{t_{1}}^{t_{2}} C(t) d t
$$

where $C(t)$ is battery charge rate at time $t$; note $C$ is positive for battery discharging and $C$ is negative for battery charging; $\eta_{b}$ is the battery coulombic efficiency.

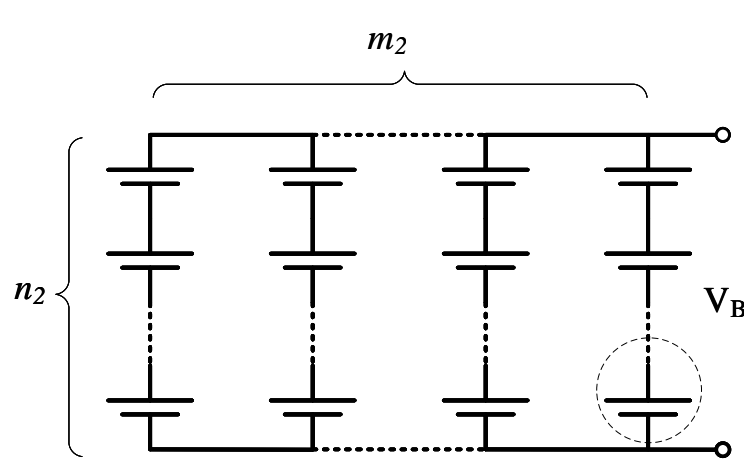

(a)

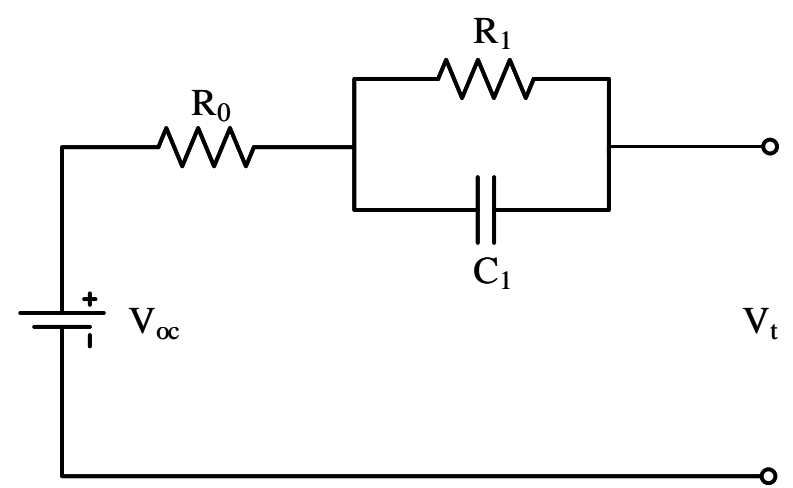

(b)

Figure 6: Battery equivalent circuit: (a) battery module schematic and (b) battery single cell equivalent circuit. 


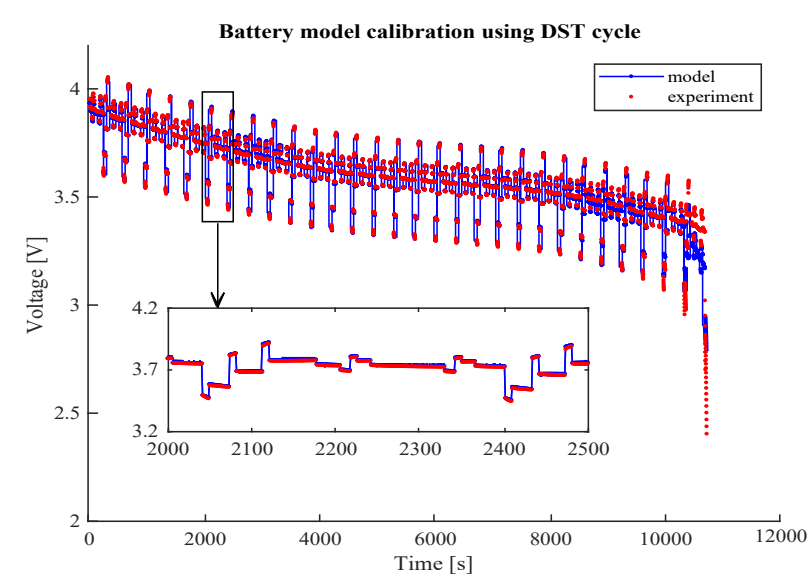

(a)

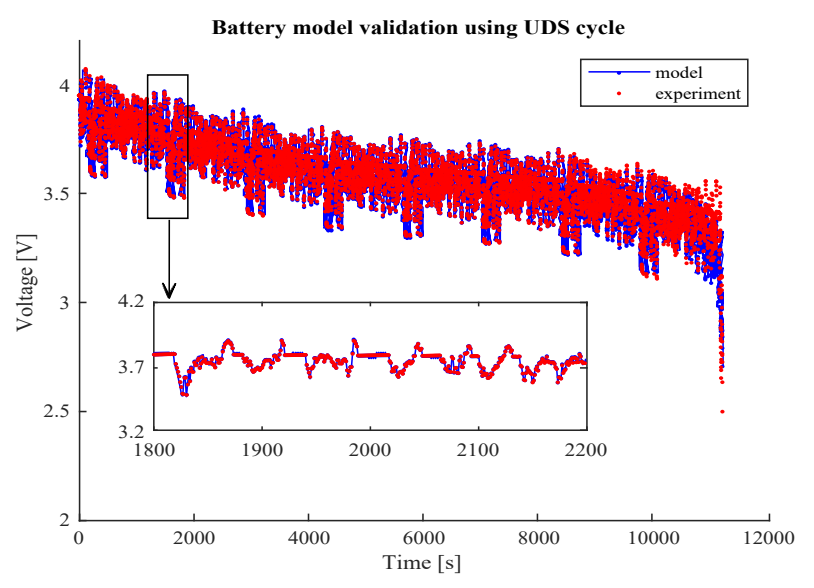

(b)

Figure 7: Battery model (a) calibration with the dynamic stress test and (b) validation using urban driving schedule.

\section{Multi-objective propulsion system optimisation}

Based upon the hybrid fuel cell and battery propulsion system model, the proposed multiobjective propulsion system sizing methodology optimises the power source sizes as shown in Figure 8. The two-layer multi-objective design methodology looks to solve the power source sizing problem by considering both emission and economic performances. An average operating profile normalised from route performance data obtained from a normal ship of similar capacity or other routines such as scaled experiments can be applied for the system optimisation. The inner layer solves the optimal power split problem for each power source sizing combination passed from the external layer to minimise average voyage cost using Deterministic Dynamic Programming (DDP) (Sundström et al., 2010). The optimisation method adopted for the external layer is Non-dominated Sorting Genetic Algorithm II, based upon the work of Deb et al. (2002). The external layer optimises the average voyage cost and GWP emissions concurrently. The decision variables of the external layer are a vector of the fuel cell and battery module sizing parameters. The trade-off between the two objectives needs to be determined manually based on the Pareto front. 


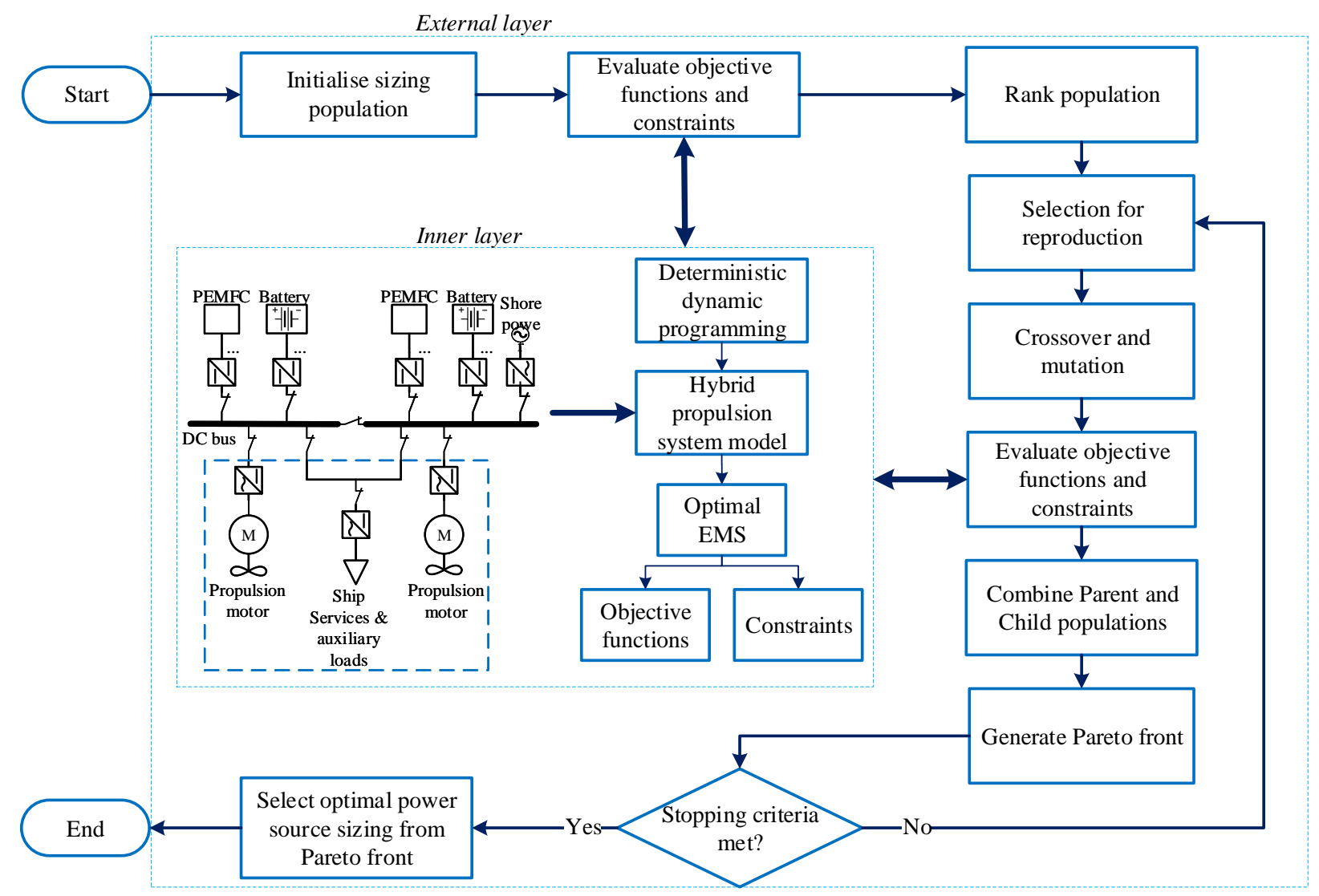

Figure 8: Proposed holistic design methodology.

\subsection{External layer}

It appears that both fuel cell and battery modules are emission-free if the scope is limited only to the ship's propulsion system. However, looking beyond the ship itself, the production of $\mathrm{H}_{2}$ and generation of shore power will have specific carbon footprints. On the other hand, the high prices, shorter life and lower energy/power densities are significant drawbacks of these technologies compared to conventional diesel engine based solutions. To balance the trade-off between emission and economic performance, a multi-objective power source sizing methodology considering both emission performance and average voyage cost is formulated 
as follows:

$$
\begin{aligned}
& \text { minimise: } F(Z)=\left[f_{1}, f_{2}\right]^{T} \\
& \text { subject to: }\left\{\begin{array}{l}
V_{x} \leq V_{D} \\
W_{x} \leq W_{D} \\
K_{1} P_{d g} \leq P_{f c}^{R}+P_{b a t, 1 C} \\
K_{2} P_{d g} \leq P_{f c}^{R}+P_{b a t, 3 C}
\end{array}\right.
\end{aligned}
$$

where $Z=\left[m_{1}, n_{1}, m_{2}, n_{2}\right]^{T}$ is a vector of power source sizing integer variables, which is constrained by its lower and upper limits $\left(Z_{1}\right.$ and $\left.Z_{2}\right) ; F(Z)$ is a vector of objective functions: $f_{1}$ is the average voyage cost including fuel cell and battery degradation costs, hydrogen cost and shore electricity costs, $f_{2}$ is voyage GWP emission comprising through life GWP emissions from hydrogen and shore electricity (Wu and Bucknall, 2018):

$$
\begin{gathered}
f_{1}=\sum_{t=1}^{T} \psi_{f c}\left(x_{t}+\frac{u_{t}}{2}\right) P_{f c} \Delta t \sigma_{H_{2}}+\sum_{t=1}^{T} \delta_{f c}\left(x_{t}+\frac{u_{t}}{2}\right) P_{f c} \sigma_{f c}+\sum_{t=J}^{T} P_{s h} \Delta t \sigma_{e}+\sum_{t=1}^{T} \delta_{b a t} B \sigma_{b a t} \\
f_{2}=\sum_{t=1}^{T} \psi_{f c}\left(x_{t}+u_{t}\right) P_{f c} \Delta t v_{H_{2}}+\sum_{t=J}^{T} P_{s h} \Delta t v_{e}
\end{gathered}
$$

where $\psi_{f c}$ is the fuel cell specific hydrogen consumption function (see Figure $5 \mathrm{~b}$ ), $x_{t}$ is the fuel cell power fraction in time step $t$ and $u_{t}$ is the fuel cell power change in time step $t$ (note that $\mathrm{H}_{2}$ consumption is calculated by an averaged fuel cell power level in one time step), $T$ is the final time step; $\delta_{f c}$ is the fuel cell degradation function and is determined by the degradation rates in Table $1 ; P_{s h}$ is shore power when the ship is in port; $\delta_{b a t}$ is an averaged battery degradation rate in each time step, assuming the batteries are guaranteed to last for a specific period; $\sigma_{H_{2}}, \sigma_{e}, \sigma_{f c}$ and $\sigma_{b a t}$ are $\mathrm{H}_{2}$, shore electricity, fuel cell and battery prices respectively; $v_{H_{2}}$ and $v_{e}$ are $\mathrm{H}_{2}$ and shore electricity GWP respectively; $B$ is battery capacity.

$V_{x}$ and $W_{x}$ are hybrid system volume and weight (including both power sources and fuels) respectively; $V_{D}$ and $W_{D}$ are original diesel system volume and weight respectively; 
$P_{f c}^{R}, P_{b a t, 1 C}, P_{b a t, 3 C}$ and $P_{d g}$ are rated fuel cell power, battery power at 1 -C, battery power at $3-\mathrm{C}$ and diesel generator rated power in the original system. The first two constraints in Eq. 12 ensures that the hybrid system volume and weight do not exceed those of the original diesel-electric system. The last two constraints guarantee that the hybrid system can provide sufficient power. $K_{1}$ is the most frequent number of diesel generators required to be on line and $K_{2}$ is the number of installed diesel generators in the original diesel-electric system.

\subsection{Inner layer-optimal EMS for the average operating profile}

The inner layer of the sizing process is solved using reverse iteration to find the optimal energy management strategy (EMS) $\pi$ for the average power profile for each feasible power source sizing combination $Z$ using DDP (Sundström et al., 2010). As a special case of stochastic dynamic programming, the transition from one state to the next is deterministic in DDP; hence the computation time is significantly reduced when compared to that of stochastic dynamic programming. DDP requires complete knowledge of voyage power demands during all time steps, which is not realistic for on-line EMS but can be used to obtain optimal off-line EMS to benchmark the quality of on-line EMS. The optimal EMS $\pi^{*}(u \mid x)$ minimises the objective function $f_{1}$ subject to the constraints listed in Eq. 15:

$$
\begin{aligned}
& u \in U \\
& S O C_{\text {min }} \leq S O C \leq S O C_{\text {max }} \\
& P_{b a t, \text { min }} \leq P_{b a t} \leq P_{b a t, \text { max }} \\
& P_{b a t, \text { port }}-P_{\text {dem,port }}+P_{\text {sh,max }} \geq 0 \\
& \left\{\begin{array}{l}
x=0, \quad \text { port mode } \\
0 \leq x \leq 1, \quad \text { sailing mode }
\end{array}\right.
\end{aligned}
$$

where $U$ is a set of fuel cell power change ratios, $x$ is fuel cell per unit power, $P_{s h, \text { max }}$ is the maximum available shore power, when $P_{b a t, p o r t}$ is negative this indicates the battery charging 
power in port mode, $P_{\text {dem,port }}$ is the ship's power demand in port mode. With the optimal EMS solved, the second objective function of GWP emissions can then be calculated.

\section{Case studies and discussion}

\subsection{Simulation settings}

In this section, the proposed hybrid fuel cell and battery propulsion system model and power sources sizing methodology are applied to a coastal ferry with the specification as presented in Table 2. The original system features an integrated full electric propulsion configuration with a total installed diesel powered capacity of $4370 \mathrm{~kW}$. It is assumed that the annual operating duty is 300 days, and the ship operates between two fixed ports with 8 rounds of trips (16 voyages) per day - each voyage taking approximately one hour. It is also assumed that the batteries can be charged at both ends of the defined voyage, and hydrogen needs to be replenished at the end of the operational day. The simulations were implemented in Matlab 2019a on a workstation with two Intel Xeon E5-2683 V3 processors and 64 GB memory.

Table 2: Case ship specification.

\begin{tabular}{ll}
\hline Parameters & Value \\
\hline Ship type & Ferry \\
Gross tonnage & 4500 \\
Power system configuration & Integrated full electric propulsion \\
Installed engine power & $4370 \mathrm{~kW}$ \\
Fuel tank volume & $140 \mathrm{~m}^{3}$ \\
Daily voyage number & 16 \\
Average voyage time & $1 \mathrm{~h}$ \\
\hline
\end{tabular}

Figure 9a shows the subject ship with its route presented in 9b (Eriksen et al., 2018). The continuous monitoring power data acquired from (Eriksen et al., 2018) was segregated into voyage power profiles by judging the ship's speed and location. An average operating 
profile based upon these profiles was generated for sizing and optimisation, as shown in Table 3. Table 4 shows the grids of state and action spaces for inner layer DDP.

The original time step of raw data used to generate the power profile was $15 \mathrm{~s}$. Such a time step was also adopted in this study. Considering the problem is solvable with available computational power, the $15 \mathrm{~s}$ time step was not increased. The DDP EMS solver in the inner layer can generate an off-line EMS in less than $1 \mathrm{~s}$ with the above mentioned settings and time step. Fletcher et al. (2016) reported that their Stochastic Dynamic Programming algorithm took approximately $6 \mathrm{~h}$ to generate an on-line EMS using a quad-core processor. Nevertheless, it is worth noting that the application of DDP is limited to off-line EMS due to the requirement of complete profile information before solving.

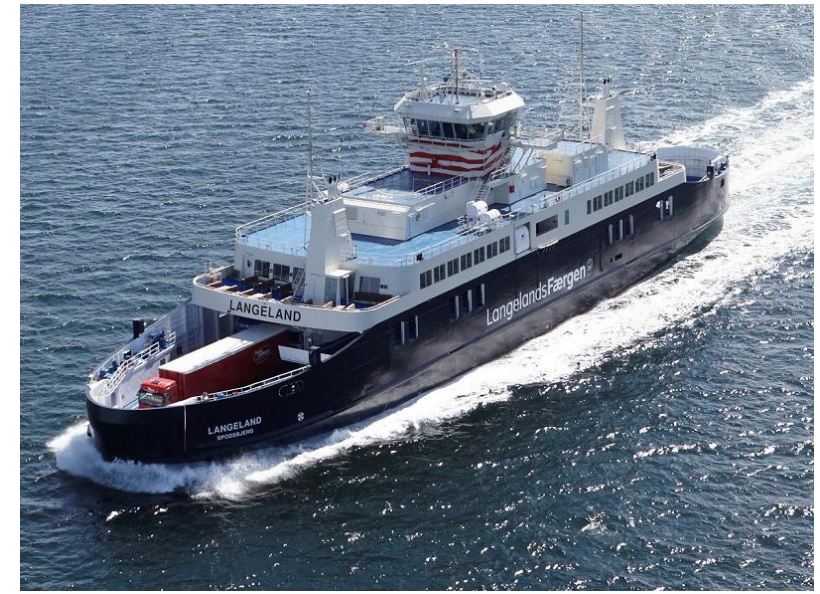

(a)

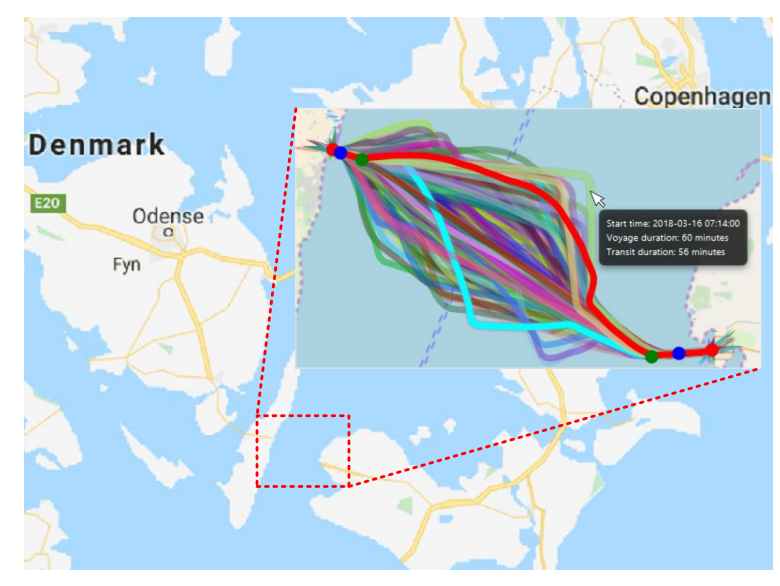

(b)

Figure 9: Case ship (a) and its route (b). 
Table 3: Average operating profile for sizing.

\begin{tabular}{lll}
\hline Parameter & Value & Unit \\
\hline Departing time & 380 & $\mathrm{~s}$ \\
Sailing time & 2785 & $\mathrm{~s}$ \\
Approaching time & 380 & $\mathrm{~s}$ \\
Sailing power & 1454 & $\mathrm{~kW}$ \\
Power at shore & 283 & $\mathrm{~kW}$ \\
\hline
\end{tabular}

Table 4: State and action space grid setting for dynamic programming.

\begin{tabular}{lll}
\hline Parameter & Grid length & Range \\
\hline Power demand & 50 & $0-4400 \mathrm{~kW}$ \\
SOC & 0.05 & $0-1$ \\
Fuel cell power level & 0.02 & $0-1$ \\
Shore power availability & - & 0 or 1 \\
Fuel cell power change fraction & 0.02 & {$[-0.04,-0.02,0,0.02,0.04]$} \\
\hline
\end{tabular}

Table 5 presents the parameters adopted in the case studies. The power sources' parameters are acquired from manufacturer's specifications. Note that the optimal design may vary for different geographical locations with different energy supply tariffs and fuel costs. Considering $\mathrm{H}_{2}$ GWP and price can depend on the method of and energy source for $\mathrm{H}_{2}$ production, $\mathrm{H}_{2}$ produced from two approaches (i.e. via nuclear-powered based and wind power based electrolysis) are considered in two case studies. The first case is for the ship's original operating area (Denmark), whereas the second case investigates how the hybrid system should be optimised assuming the ship operates in UK waters. 
Table 5: Case study parameters.

\begin{tabular}{|c|c|c|c|c|}
\hline Category & Parameter & Value & Unit & Reference \\
\hline \multirow[t]{2}{*}{ Diesel system } & Original diesel generator system volume & 294 & $\mathrm{~m}^{3}$ & (Caterpillar, 2018) \\
\hline & Original diesel generator system weight & 156 & $\mathrm{t}$ & \\
\hline \multirow[t]{2}{*}{ Marine gas oil } & Marine gas oil price & 0.64 & $\$ \mathrm{~kg}^{-1}$ & (BunkerIndex, 2017) \\
\hline & Marine gas oil GWP & 3.2 & $\mathrm{~kg} \mathrm{CO} \mathrm{kg}^{-1}$ & (Kristensen, 2012) \\
\hline \multirow[t]{5}{*}{ PEMFC system } & PEMFC price & 830 & $\$ \mathrm{~kW}^{-1}$ & (Raucci, 2017) \\
\hline & PEMFC volumetric specific power & 128 & $\mathrm{~kW} \mathrm{~m}^{-3}$ & (Ballard, 2019) \\
\hline & PEMFC gravimetric specific power & 200 & $\mathrm{~kW} \mathrm{t}^{-1}$ & \\
\hline & $\mathrm{H}_{2}$ tank volume & 0.17 & $\mathrm{~m}^{3} \mathrm{~kg}^{-1} \mathrm{H}_{2}$ & (Choi et al., 2016) \\
\hline & $\mathrm{H}_{2}$ tank weight & 28.5 & $\mathrm{~kg} \mathrm{~kg}^{-1} \mathrm{H}_{2}$ & \\
\hline \multirow[t]{7}{*}{ Battery system } & Battery price & 800 & $\$ \mathrm{kWh}^{-1}$ & (Ovrum and Dimopoulos, 2012) \\
\hline & Battery life time & 1.5 & year & (Stroe et al., 2015) \\
\hline & Battery volumetric specific energy & 91.8 & $\mathrm{~kW} \mathrm{~h} \mathrm{~m}^{-3}$ & (Corvus, 2017) \\
\hline & Battery gravimetric specific energy & 80.6 & $\mathrm{kWht}^{-1}$ & \\
\hline & Battery SOC higher limit & 0.25 & & \\
\hline & Battery SOC lower limit & 0.90 & & \\
\hline & Battery maximum C-rate & 6 & $\mathrm{C}$ & \\
\hline \multirow[t]{2}{*}{ UK electricity } & Shore electricity price & 0.16 & $\$ \mathrm{kWh}^{-1}$ & (Eurostat, 2019) \\
\hline & Shore electricity GWP & 0.28 & $\mathrm{~kg} \mathrm{CO} \mathrm{kWh}^{-1}$ & \\
\hline \multirow[t]{2}{*}{ Denmark electricity } & Shore electricity price & 0.09 & $\$ \mathrm{kWh}^{-1}$ & \\
\hline & Shore electricity GWP & 0.17 & $\mathrm{~kg} \mathrm{CO} \mathrm{kWh}^{-1}$ & \\
\hline \multirow[t]{2}{*}{ Nuclear-powered electrolysis $\mathrm{H}_{2}$} & $\mathrm{H}_{2}$ price & 3.50 & $\$ \mathrm{~kg}^{-1}$ & (Acar and Dincer, 2014) \\
\hline & $\mathrm{H}_{2} \mathrm{GWP}$ & 2.40 & $\mathrm{~kg} \mathrm{CO} \mathrm{kg}^{-1}$ & \\
\hline \multirow[t]{2}{*}{ Wind-powered electrolysis $\mathrm{H}_{2}$} & $\mathrm{H}_{2}$ price & 8.24 & $\$ \mathrm{~kg}^{-1}$ & \\
\hline & $\mathrm{H}_{2} \mathrm{GWP}$ & 1.50 & $\mathrm{~kg} \mathrm{CO} \mathrm{kg}^{-1}$ & \\
\hline
\end{tabular}

\subsection{Denmark case}

For the case of Denmark, detailed fuel cell and battery sizing combinations with regards to the cost and emission objectives are presented in Figure 10 for the two considered two $\mathrm{H}_{2}$ scenarios. In the scenario of $\mathrm{H}_{2}$ via nuclear-powered high temperature electrolysis (Figure 10a), the minimum voyage GWP can be achieved is about $155 \mathrm{~kg} \mathrm{CO}_{2}$, at the voyage cost $\$ 610$. This minimum GWP corresponds to a PEMFC power of $4320 \mathrm{~kW}$ and a battery capacity of $37 \mathrm{kWh}$. Note that the fuel cell power at this point is very close to the original total diesel engine power of $4370 \mathrm{~kW}$, and the battery capacity is comparatively negligible when compared to the installed fuel cell power. Such an observation suggest that, given 
the case study parameters, to achieve extremely low GWP emissions, a large fuel cell plant with relatively small battery capacity would be the preferred solution. However, it would be more reasonable to select the design point around fuel cell power of $2915 \mathrm{~kW}$ and battery capacity of $600 \mathrm{kWh}$, which corresponds the knee point (voyage cost of $\$ 480$ and GWP of $170 \mathrm{~kg}$ ) of the Pareto front as in Figure 10a. Such a design point avoids unfavourably large cost sacrifice to achieve minimal improvement in emission performance.

For the scenario of $\mathrm{H}_{2}$ via wind-powered electrolysis (Figure 10b), an even lower GWP can be achieved $\left(105 \mathrm{~kg} \mathrm{CO}_{2}\right)$ due to the GWP of this $\mathrm{H}_{2}$ approach $\left(1.5 \mathrm{~kg} \mathrm{CO}_{2} \mathrm{~kg}^{-1}\right)$ is much lower than that from the nuclear-powered approach. However, such a low GWP emission would lead to a voyage cost of $\$ 900$. It is also true that a large fuel cell plant leads to lower emissions. A large battery plant can achieve lower average voyage cost (minimum $\$ 615$ per voyage). In practice, when choosing the design point, other factors need to be considered with reference to these Pareto fronts. 


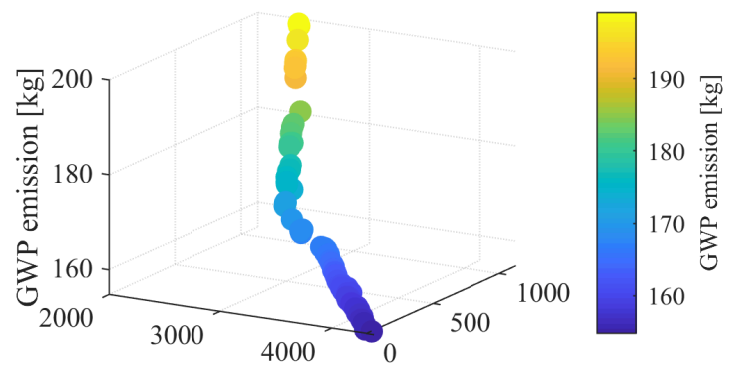

PEMFC power [kW]

Battery capacity [kWh]
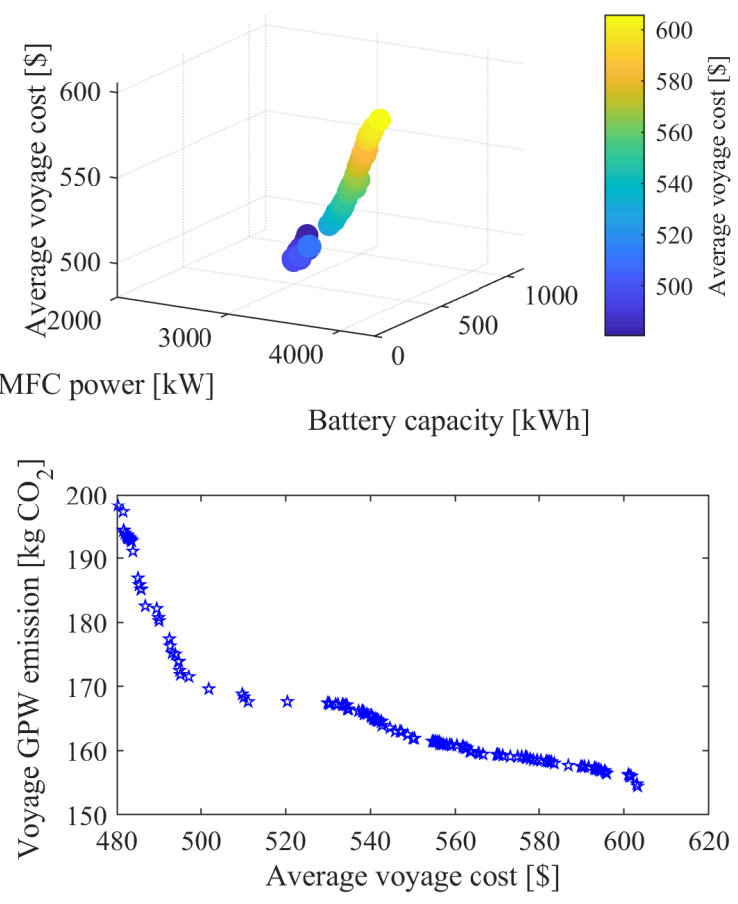

(a)

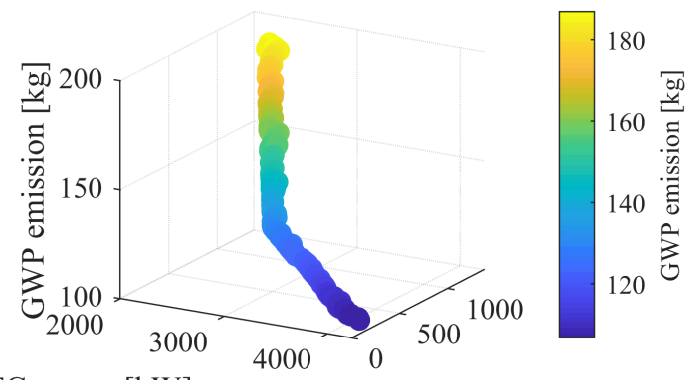

PEMFC power [kW]

Battery capacity [kWh]

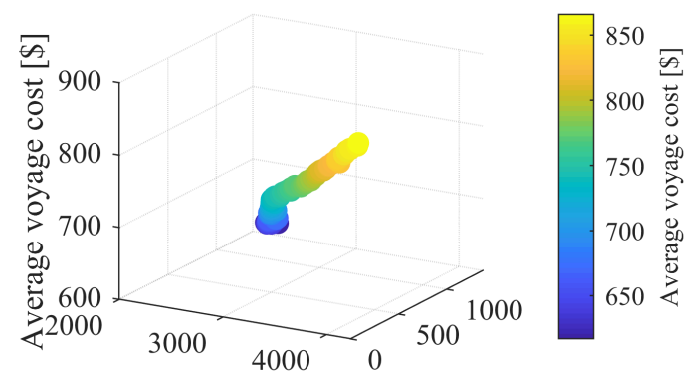

PEMFC power [kW]

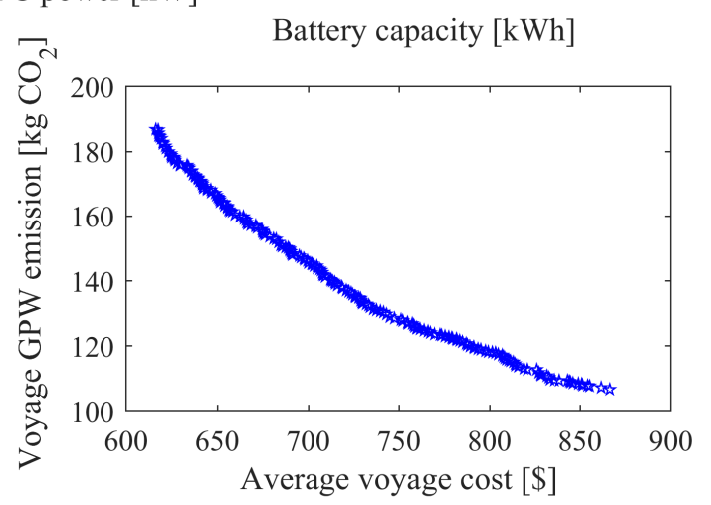

(b)

Figure 10: Denmark case: (a) $\mathrm{H}_{2}$ via nuclear-powered high temperature electrolysis and (b) $\mathrm{H}_{2}$ via windpowered electrolysis.

\subsubsection{Optimal EMS}

To further illustrate the optimal EMS (Section 3.2), based on the Pareto front shown in Figure 10b, a design point of fuel cell power of $2940 \mathrm{~kW}$ and battery capacity of $581 \mathrm{~kW}$ h is selected for demonstration. Figure 11 shows the optimal EMS for the selected power source design under the averaged operating profile (Table 3). The battery modules provide power solely during departure and deliver a small portion of power while cruising. As this operating 
profile is averaged for sizing and does not include power transients, the optimal EMS does not charge the battery during sailing (i.e. the battery power flow is never negative during sailing). When the ship is in port, the fuel cell is switched to idle while the batteries are charged by shore power. Note that such an EMS is solved by DDP, and the entire profile is known in advance.

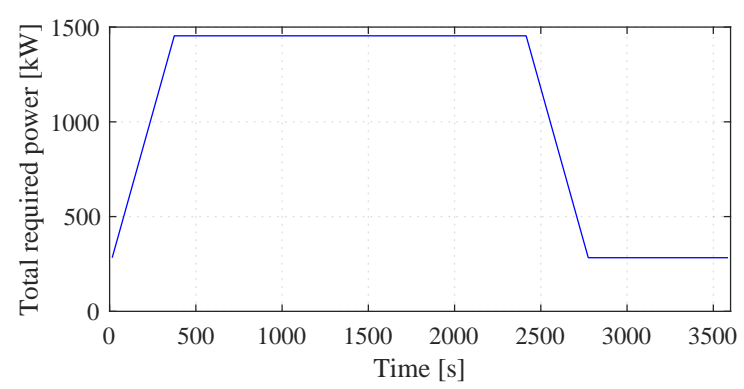

(a)

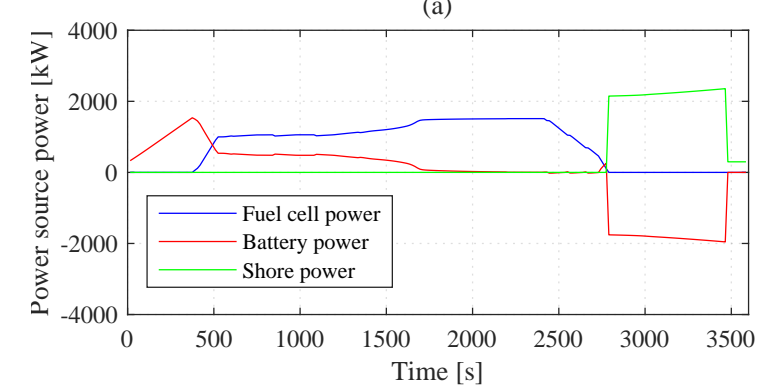

(b)

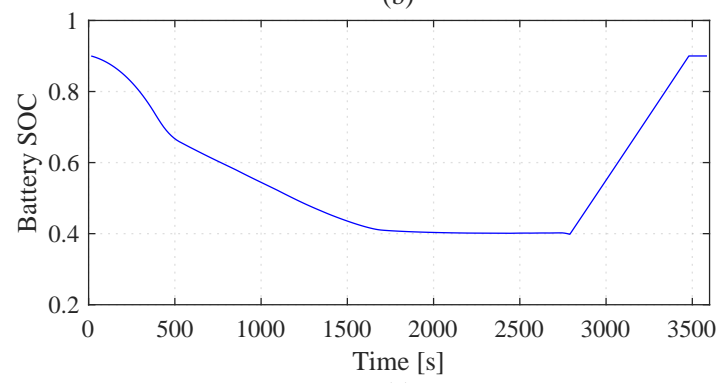

(c)

Figure 11: DDP solved EMS for averaged power profile of selected power source sizing: (a) averaged power profile, (b) power distribution between power sources and (c) battery SOC trajectory.

To better understand the compositions of voyage cost and emission of the selected design point discussed in Section 4.2.1, Table 6 shows the cost and emission breakdown of the proposed hybrid and original systems. Hydrogen cost contributes more than $50 \%$ of the average cost. The fuel cell degradation cost is a significant source as well. The total GWP emission is reduced by $85 \%$ with $226 \%$ cost increase compared to the original diesel-electric 
system. The hybrid system is more expensive than the conventional diesel engine based system. However, the Pareto front could vary significantly if parameters like fuel cell price or $\mathrm{H}_{2}$ prices change.

Table 6: Voyage cost and GWP emission breakdown

\begin{tabular}{lll}
\hline & Cost $[\$]$ & GWP emission $[\mathrm{kg} \mathrm{CO}]$ \\
\hline Fuel cell & 238 & - \\
Hydrogen & 368 & 67 \\
Battery & 65 & - \\
Shore electricity & 39 & 123 \\
Total & 710 & 190 \\
\hline Diesel engine & 46 & - \\
Diesel fuel & 168 & 838 \\
Shore electricity & 4 & 4 \\
Total & 218 & 842 \\
\hline
\end{tabular}

\subsection{UK case}

To understand how the proposed hybrid system should be optimised if it operates in UK waters, further investigations of the two $\mathrm{H}_{2}$ scenarios are shown in Figure 12a and 12b. Similar to the Denmark case, larger fuel cells lead to lower GPW in both $\mathrm{H}_{2}$ scenarios. Due to UK non-household electricity costs being higher than that of Denmark, the minimum voyage costs are $\$ 510$ (12a) and $\$ 670$ (12b) respectively. It is worth noting that, the maximum voyage GWP for the wind-powered electrolysis (12b) is $290 \mathrm{~kg} \mathrm{CO}_{2}(65 \% \mathrm{GWP}$ emission reduction compared to the original diesel-electric configuration), whereas it is only $185 \mathrm{~kg}$ $\mathrm{CO}_{2}$ for the Denmark case. As presented in 12a, increasing the fuel cell power from 2900 to $3090 \mathrm{~kW}$ (corresponding battery capacity is $425 \mathrm{~kW} \mathrm{~h}$ ) would bring down the voyage GWP down from 215 to $200 \mathrm{~kg} \mathrm{CO}_{2}$. However, it is more challenging to further reduce voyage GWP by increasing installed fuel cell power beyond this knee point. As shown in $12 \mathrm{~b}$, the 
knee point is around the fuel cell power of $3060 \mathrm{~kW}$ and the battery capacity of $450 \mathrm{kWh}$. This knee point provides an average voyage cost of $\$ 750$ and and GWP of $170 \mathrm{~kg} \mathrm{CO}_{2}$. Comparing $12 \mathrm{a}$ and $12 \mathrm{~b}$, wind-power based $\mathrm{H}_{2}$ would provide much lower voyage GWP (minimum $110 \mathrm{~kg} \mathrm{CO}_{2}$ ), though the cheapest sizing solution is still more expensive than $\$ 600$ (maximum voyage cost appeared in 12a).

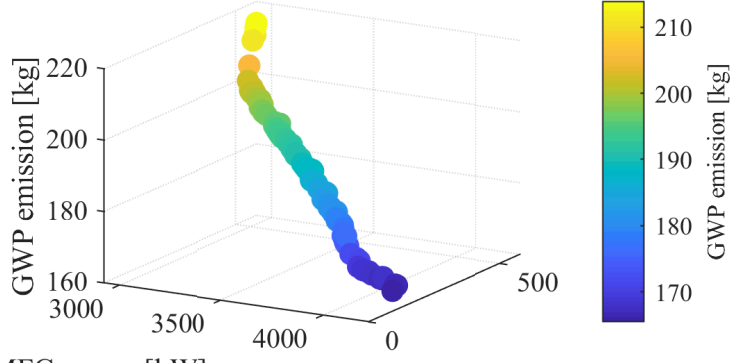

PEMFC power $[\mathrm{kW}]$

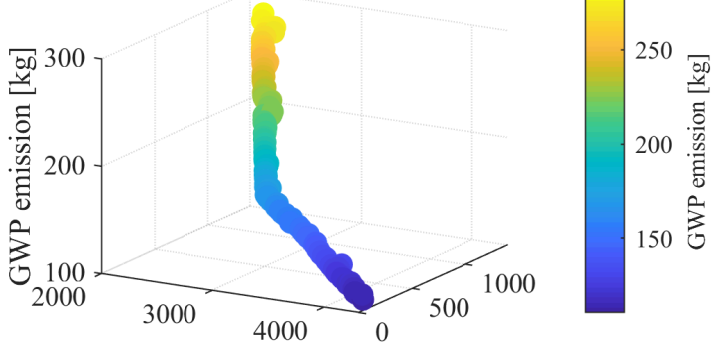

PEMFC power $[\mathrm{kW}]$

Battery capacity $[\mathrm{kWh}]$

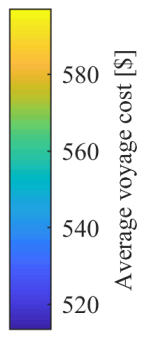

PEMFC power $[\mathrm{kW}]$
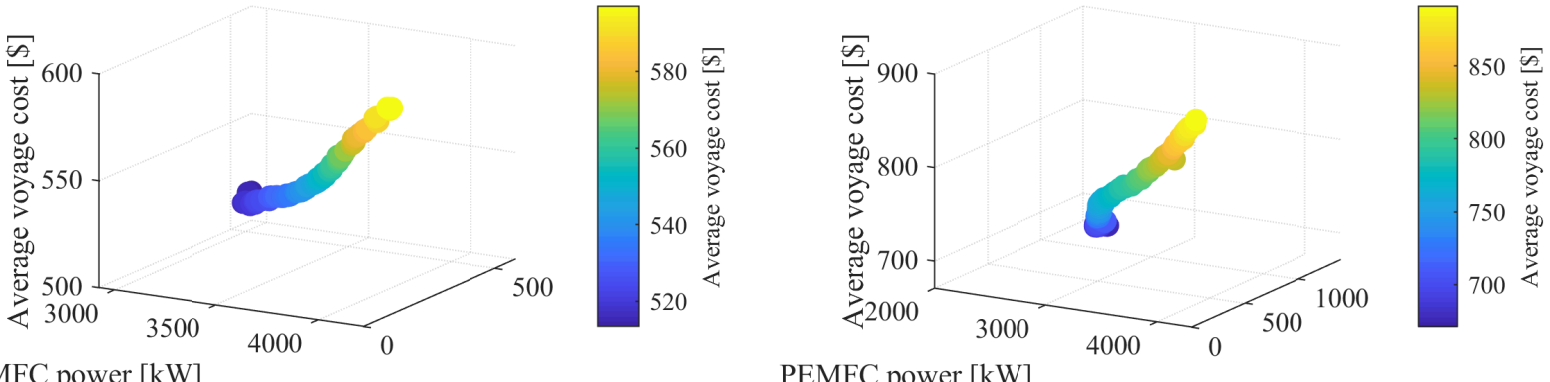

PEMFC power $[\mathrm{kW}]$

Battery capacity $[\mathrm{kWh}]$

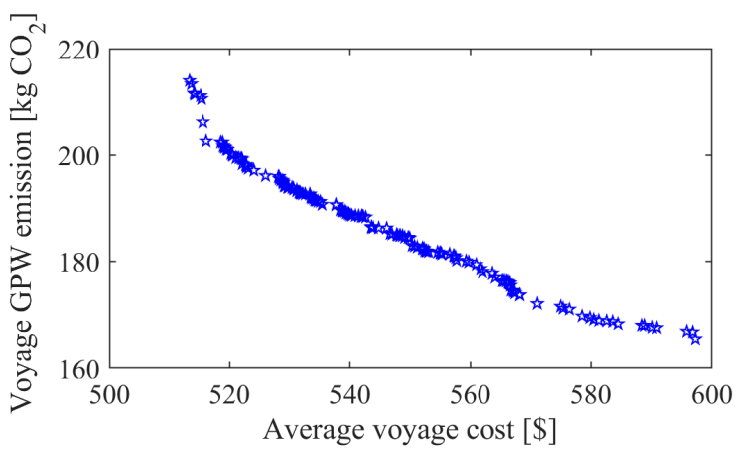

(a)

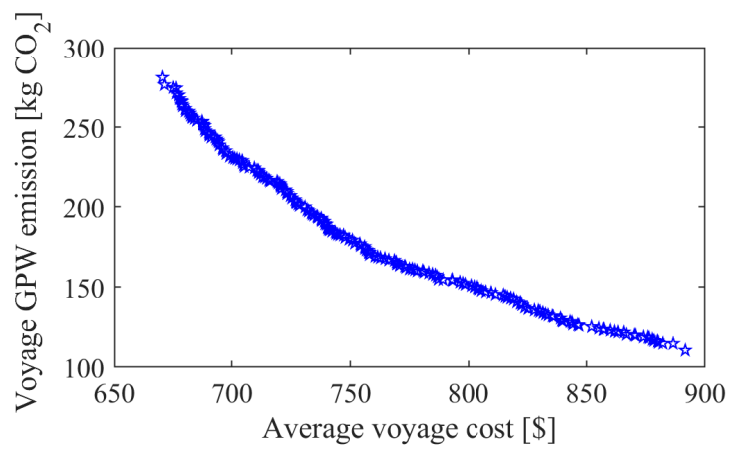

(b)

Figure 12: UK case: (a) $\mathrm{H}_{2}$ via nuclear-powered high temperature electrolysis and (b) $\mathrm{H}_{2}$ via wind-powered electrolysis. 


\section{Conclusions and future work}

This paper presents a plug-in hybrid PEMFC/battery system model and an improved multi-objective design methodology for such systems. The model and optimisation methodology have been applied to a coastal ferry to optimise its plug-in hybrid fuel cell and battery propulsion system via two case studies. Power source degradations and optimal energy management between multiple power sources are considered in the optimisation. It is evident that such a PEMFC/battery hybrid system can significantly reduce the GWP emission, but is still constrained by high costs, mainly from $\mathrm{H}_{2}$ cost of production and fuel cell degradation. The multi-objective power source sizing methodology can be used to guide alternative propulsion system design considering the influences of energy through-life properties and power source degradation characteristics. For the two cases considered with two $\mathrm{H}_{2}$ scenarios, a minimum $65 \%$ GWP emission reduction can be achieved by utilising the plug-in hybrid fuel cell and battery propulsion system configuration.

In the inner layer of the optimisation scheme, an averaged operating profile is considered for design optimisation. In future work, real-time energy management strategies for future non-predicted profiles will be developed to manage power flows between multiple power sources effectively.

\section{Acknowledgements}

The authors thank Jens Christian Bjeldorf from Molslinje A/S for approving using the ship data in this study. The authors are grateful to Stig Eriksen and his colleagues for collecting the ship data. The authors are also indebted to Konrad Yearwood for his valuable critique of this paper. The first author would like to thank University College London (UCL) Faculty of Engineering Sciences and China Scholarship Council for supporting his studies at UCL.

ABB, 2018. ForSea (formerly HH Ferries Group) completes conversion of the world's largest battery ferries, powered by ABB. URL: https://new.abb.com/news/detail/10434/forsea-formerly-hh-ferriesgroup-completes-conversion-of-the-worlds-largest-battery-ferries-powered-by-abb. [Accessed 11th Oct 2019]. 
Abdin, Z., Webb, C., Gray, E.M., 2016. PEM fuel cell model and simulation in Matlab-Simulink based on physical parameters. Energy 116, 1131-1144. doi:10.1016/j.energy .2016.10.033.

Acar, C., Dincer, I., 2014. Comparative assessment of hydrogen production methods from renewable and non-renewable sources. International Journal of Hydrogen Energy 39, 1-12. doi:10.1016/j.ijhydene. 2013.10 .060 .

Alaswad, A., Baroutaji, A., Achour, H., Carton, J., Al Makky, A., Olabi, A.G., 2016. Developments in fuel cell technologies in the transport sector. International Journal of Hydrogen Energy 41, 16499-16508. doi:10.1016/j.ijhydene.2016.03.164.

Ang, S.M.C., Brett, D.J., Fraga, E.S., 2010. A multi-objective optimisation model for a general polymer electrolyte membrane fuel cell system. Journal of Power Sources 195, 2754-2763. doi:10.1016/j.jpowsour. 2009.10.095.

Ballard, 2019. Fuel Cell Power Module for Heavy Duty Motive Applications. URL: http: //www.ballard.com/docs/default-source/motive-modules-documents/fcvelocity_hd_family_ of_products_low_res.pdf. [Accessed 21st Feb 2019].

Bassam, A., 2017. Use of voyage simulation to investigate hybrid fuel cell systems for marine propulsion. Ph.D. thesis. University of Southampton.

Boscarato, I., Hickey, N., Kašpar, J., Prati, M.V., Mariani, A., 2015. Green shipping: Marine engine pollution abatement using a combined catalyst/seawater scrubber system. 1. Effect of catalyst. Journal of Catalysis 328, 248-257. doi:10.1016/j.jcat.2014.12.013.

Brynolf, S., Fridell, E., Andersson, K., 2014. Environmental assessment of marine fuels: liquefied natural gas, liquefied biogas, methanol and bio-methanol. Journal of Cleaner Production 74, 86-95. doi:10.1016/ j.jclepro.2014.03.052.

BunkerIndex, 2017. Index Summary. URL: http://www. bunkerindex.com/. [Accessed 28th Oct 2017].

Cames, M., Graichen, J., Siemons, A., Cook, V., 2015. Emission reduction targets for international aviation and shipping. Report. European Parliament. URL: http://www . europarl . europa.eu/RegData/etudes/ STUD/2015/569964/IPOL_STU(2015)569964_EN.pdf.

Caterpillar, 2018. Marine power systems C32 TIER 3/IMO II. URL: https://www.cat.com/en_GB/ products/new/power-systems/marine-power-systems/marine-generator-sets/1000031744.html. [Accessed 20th Jan 2018].

Chen, H., Pei, P., Song, M., 2015. Lifetime prediction and the economic lifetime of proton exchange membrane fuel cells. Applied Energy 142, 154-163. doi:10.1016/j .apenergy .2014.12.062.

Choi, C.H., Yu, S., Han, I.S., Kho, B.K., Kang, D.G., Lee, H.Y., Seo, M.S., Kong, J.W., Kim, G., Ahn, J.W., Park, S.K., Jang, D.W., Lee, J.H., Kim, M., 2016. Development and demonstration of PEM fuelcell-battery hybrid system for propulsion of tourist boat. International Journal of Hydrogen Energy 41, 
3591-3599. doi:10.1016/j.ijhydene.2015.12.186.

Corbett, J.J., Fischbeck, P.S., Pandis, S.N., 1999. Global nitrogen and sulfur inventories for oceangoing ships. Journal of Geophysical Research: Atmospheres 104, 3457-3470. doi:10.1029/1998JD100040.

Corvus, E., 2017. Orca Energy Specifications. URL: http://corvusenergy.com/technologyspecifications/. [Accessed 10th Oct 2017].

Corvus, E., 2019. Corvus Energy awarded the marine world's biggest battery package for hybrid powered vessel by Norwegian Electric Systems. URL: https://corvusenergy.com/corvus-energy-awarded-themarine-worlds-biggest-battery-package-by-norwegian-electric-systems/. [Accessed 20th May 2019].

Deb, K., Pratap, A., Agarwal, S., Meyarivan, T., 2002. A fast and elitist multiobjective genetic algorithm: Nsga-ii. IEEE transactions on evolutionary computation 6, 182-197.

Deniz, C., Zincir, B., 2016. Environmental and economical assessment of alternative marine fuels. Journal of Cleaner Production 113, 438-449. doi:10.1016/j.jclepro.2015.11.089.

Di Natale, F., Carotenuto, C., 2015. Particulate matter in marine diesel engines exhausts: Emissions and control strategies. Transportation Research Part D: Transport and Environment 40, 166-191. doi:10. $1016 / j \cdot \operatorname{trd} .2015 .08 .011$.

Dicks, A.L., Rand, D.A., 2018. Fuel cell systems explained. John Wiley \& Sons.

Ekanem Attah, E., Bucknall, R., 2015. An analysis of the energy efficiency of LNG ships powering options using the EEDI. Ocean Engineering 110, 62-74. doi:10.1016/j .oceaneng.2015.09.040.

Endresen, Ø., Sørgård, E., Sundet, J.K., Dalsøren, S.B., Isaksen, I.S.A., Berglen, T.F., Gravir, G., 2003. Emission from international sea transportation and environmental impact. Journal of Geophysical Research: Atmospheres 108. doi:10.1029/2002JD002898.

Eriksen, S., Lützen, M., Jensen, J.B., Sørensen, J.C., 2018. Improving the energy efficiency of ferries by optimizing the operational practices, in: Proceedings of the Full Scale Ship Performance Conference 2018: The Royal Institution of Naval Architects, The Royal Institution of Naval Architects. pp. 101-111.

European Environment Agency, 2017. Overview of electricity production and use in Europe. Report. European Environment Agency. URL: https://www.eea.europa.eu/data-and-maps/indicators/ overview-of-the-electricity-production-2/assessment. [Accessed 20th Jan 2017].

Eurostat, 2019. Electricity price statistics. URL: http://ec.europa.eu/eurostat/statisticsexplained/index.php/Electricity_price_statistics. [Accessed 10th Feb 2019].

Eyring, V., Isaksen, I.S.A., Berntsen, T., Collins, W.J., Corbett, J.J., Endresen, O., Grainger, R.G., Moldanova, J., Schlager, H., Stevenson, D.S., 2010. Transport impacts on atmosphere and climate: Shipping. Atmospheric Environment 44, 4735-4771. doi:10.1016/j . atmosenv.2009.04.059.

Fletcher, T., Thring, R., Watkinson, M., 2016. An energy management strategy to concurrently optimise 
fuel consumption \& pem fuel cell lifetime in a hybrid vehicle. international journal of hydrogen energy 41, 21503-21515. doi:10.1016/j.ijhydene.2016.08.157.

Hannan, M.A., Hoque, M.M., Mohamed, A., Ayob, A., 2017. Review of energy storage systems for electric vehicle applications: Issues and challenges. Renewable and Sustainable Energy Reviews 69, 771-789. doi:10.1016/j.rser.2016.11.171.

Hansen, J.F., Wendt, F., 2015. History and State of the Art in Commercial Electric Ship Propulsion, Integrated Power Systems, and Future Trends. Proceedings of the IEEE 103, 2229-2242. doi:10.1109/ JPROC. 2015.2458990.

Hu, X., Johannesson, L., Murgovski, N., Egardt, B., 2015. Longevity-conscious dimensioning and power management of the hybrid energy storage system in a fuel cell hybrid electric bus. Applied Energy 137, 913-924. doi:10.1016/j . apenergy .2014.05.013.

International Maritime Organization, 2014. Third IMO Greenhous Gas study 2014. Report. International Maritime Organization.

Kalikatzarakis, M., Geertsma, R., Boonen, E., Visser, K., Negenborn, R., 2018. Ship energy management for hybrid propulsion and power supply with shore charging. Control Engineering Practice 76, 133-154. doi:10.1016/j. conengprac. 2018.04.009.

Kanstad, T., Lillholm, M.B., Zhang, Z., 2019. Highly Efficient EV Battery Charger Using Fractional Charging Concept with SiC Devices, in: 2019 IEEE Applied Power Electronics Conference and Exposition (APEC), IEEE. pp. 1601-1608. doi:10.1109/APEC. 2019.8722191.

Kay, R., Alder, J., 2017. Coastal planning and management. CRC Press, London.

Kim, M.J., Peng, H., 2007. Power management and design optimization of fuel cell/battery hybrid vehicles. Journal of Power Sources 165, 819-832. doi:10.1016/j.jpowsour.2006.12.038.

Kristensen, H.O., 2012. Energy demand and exhaust gas emissions of marine engines. Clean Shipping Currents 1, 18-26.

Larcher, D., Tarascon, J.M., 2015. Towards greener and more sustainable batteries for electrical energy storage. Nature chemistry 7, 19. doi:10.1038/nchem. 2085.

Liang, M., Liu, Y., Xiao, B., Yang, S., Wang, Z., Han, H., 2018. An analytical model for the transverse permeability of gas diffusion layer with electrical double layer effects in proton exchange membrane fuel cells. International Journal of Hydrogen Energy 43, 17880-17888. doi:doi.org/10.1016/j.ijhydene. 2018.07.186.

Luo, X., Wang, J., Dooner, M., Clarke, J., 2015. Overview of current development in electrical energy storage technologies and the application potential in power system operation. Applied Energy 137, 511536. doi:10.1016/j . apenergy . 2014.09.081.

McConnell, V.P., 2010. Now, voyager? the increasing marine use of fuel cells. Fuel Cells Bulletin 2010, 
12-17. doi:10.1016/S1464-2859(10)70166-8.

Musio, F., Tacchi, F., Omati, L., Gallo Stampino, P., Dotelli, G., Limonta, S., Brivio, D., Grassini, P., 2011. Pemfc system simulation in matlab-simulink@ environment. International Journal of Hydrogen Energy 36, 8045-8052. doi:10.1016/j.ijhydene.2011.01.093.

Ovrum, E., Bergh, T.F., 2015. Modelling lithium-ion battery hybrid ship crane operation. Applied Energy 152, 162-172. doi:10.1016/j.apenergy.2015.01.066.

Ovrum, E., Dimopoulos, G., 2012. A validated dynamic model of the first marine molten carbonate fuel cell. Applied Thermal Engineering 35, 15-28. doi:10.1016/j . applthermaleng.2011.09.023.

Pukrushpan, J.T., 2003. Modeling and control of fuel cell systems and fuel processors. Ph.D. thesis. University of Michigan Ann Arbor, Michigan, USA.

Pukrushpan, J.T., Stefanopoulou, A.G., Peng, H., 2002. Modeling and control for pem fuel cell stack system, in: American Control Conference, 2002. Proceedings of the 2002, IEEE. pp. 3117-3122. doi:10.1109/ ACC . 2002.1025268.

Raucci, C., 2017. The potential of hydrogen to fuel international shipping. Ph.D. thesis. UCL (University College London).

Sasank, B.V., Rajalakshmi, N., Dhathathreyan, K.S., 2016. Performance analysis of polymer electrolyte membrane (PEM) fuel cell stack operated under marine environmental conditions. Journal of Marine Science and Technology 21, 471-478. doi:10.1007/s00773-016-0369-y.

Sharaf, O.Z., Orhan, M.F., 2014. An overview of fuel cell technology: Fundamentals and applications. Renewable and Sustainable Energy Reviews 32, 810-853. doi:10.1016/j.rser.2014.01.012.

Stefanatos, I.C., Dimopoulos, G.G., Kakalis, N.M.P., Vartdal, B.j., Ovrum, E., 2015. Modelling and simulation of hybrid-electric propulsion systems : the Viking Lady case, in: 12th International Marine Design Conference, The Japan Society of Naval Architects and Ocean Engineers, Tokyo. pp. 161-178.

Stroe, A.I., Swierczynski, M., Stroe, D.I., Teodorescu, R., 2015. Performance model for high-power lithium titanate oxide batteries based on extended characterization tests, in: 2015 IEEE Energy Conversion Congress and Exposition (ECCE), pp. 6191-6198. doi:10.1109/ECCE.2015.7310528.

Sundström, O., Ambühl, D., Guzzella, L., 2010. On implementation of dynamic programming for optimal control problems with final state constraints. Oil \& Gas Science and Technology-Revue de l'Institut Français du Pétrole 65, 91-102. doi:10.2516/ogst/2009020.

Thomson, H., Corbett, J.J., Winebrake, J.J., 2015. Natural gas as a marine fuel. Energy Policy 87, $153-167$. doi:10.1016/j.enpol.2015.08.027.

de Troya, J.J., Álvarez, C., Fernández-Garrido, C., Carral, L., 2016. Analysing the possibilities of using fuel cells in ships. International Journal of Hydrogen Energy 41, 2853-2866. doi:10.1016/j .ijhydene.2015. 11.145 . 
Tseng, K.C., Chen, C.T., Cheng, C.A., 2016. A high-efficiency high step-up interleaved converter with a voltage multiplier for electric vehicle power management applications. Journal of Power Electronics 16, 414-424. doi:10.6113/JPE. 2016.16.2.414.

Van Biert, L., Godjevac, M., Visser, K., Aravind, P., 2016. A review of fuel cell systems for maritime applications. Journal of Power Sources 327, 345-364. doi:10.1016/j.jpowsour.2016.07.007.

Vergara, J., McKesson, C., Walczak, M., 2012. Sustainable energy for the marine sector. Energy Policy 49, 333-345. doi:10.1016/j.enpol.2012.06.026.

Verschaeren, R., Schaepdryver, W., Serruys, T., Bastiaen, M., Vervaeke, L., Verhelst, S., 2014. Experimental study of NOx reduction on a medium speed heavy duty diesel engine by the application of EGR (exhaust gas recirculation) and Miller timing. Energy 76, 614-621. doi:10.1016/j.energy. 2014.08.059.

Viana, M., Hammingh, P., Colette, A., Querol, X., Degraeuwe, B., Vlieger, I.d., van Aardenne, J., 2014. Impact of maritime transport emissions on coastal air quality in europe. Atmospheric Environment 90, 96-105. doi:10.1016/j.atmosenv . 2014.03.046.

Wu, P., Bucknall, R., 2018. On the design of plug-in hybrid fuel cell and lithium battery propulsion systems for coastal ships, in: Kujala, P., Lu, L. (Eds.), 13th International Marine Design Conference (IMDC 2018), CRC Press/Balkema, London. pp. 941-951.

Xie, Y., Savvaris, A., Tsourdos, A., 2018. Sizing of hybrid electric propulsion system for retrofitting a midscale aircraft using non-dominated sorting genetic algorithm. Aerospace Science and Technology 82-83, 323-333. doi:10.1016/j . ast.2018.09.022.

Xu, L., Mueller, C.D., Li, J., Ouyang, M., Hu, Z., 2015. Multi-objective component sizing based on optimal energy management strategy of fuel cell electric vehicles. Applied Energy 157, 664-674. doi:10.1016/j . apenergy.2015.02.017.

Yan, Q., Toghiani, H., Causey, H., 2006. Steady state and dynamic performance of proton exchange membrane fuel cells (PEMFCs) under various operating conditions and load changes. Journal of Power Sources 161, 492-502. doi:10.1016/j.jpowsour.2006.03.077.

Zheng, F., Xing, Y., Jiang, J., Sun, B., Kim, J., Pecht, M., 2016. Influence of different open circuit voltage tests on state of charge online estimation for lithium-ion batteries. Applied Energy 183, 513-525. doi:10.1016/j. apenergy .2016.09.010. 


\section{Appendix}

Table 7: PEMFC governing equations.

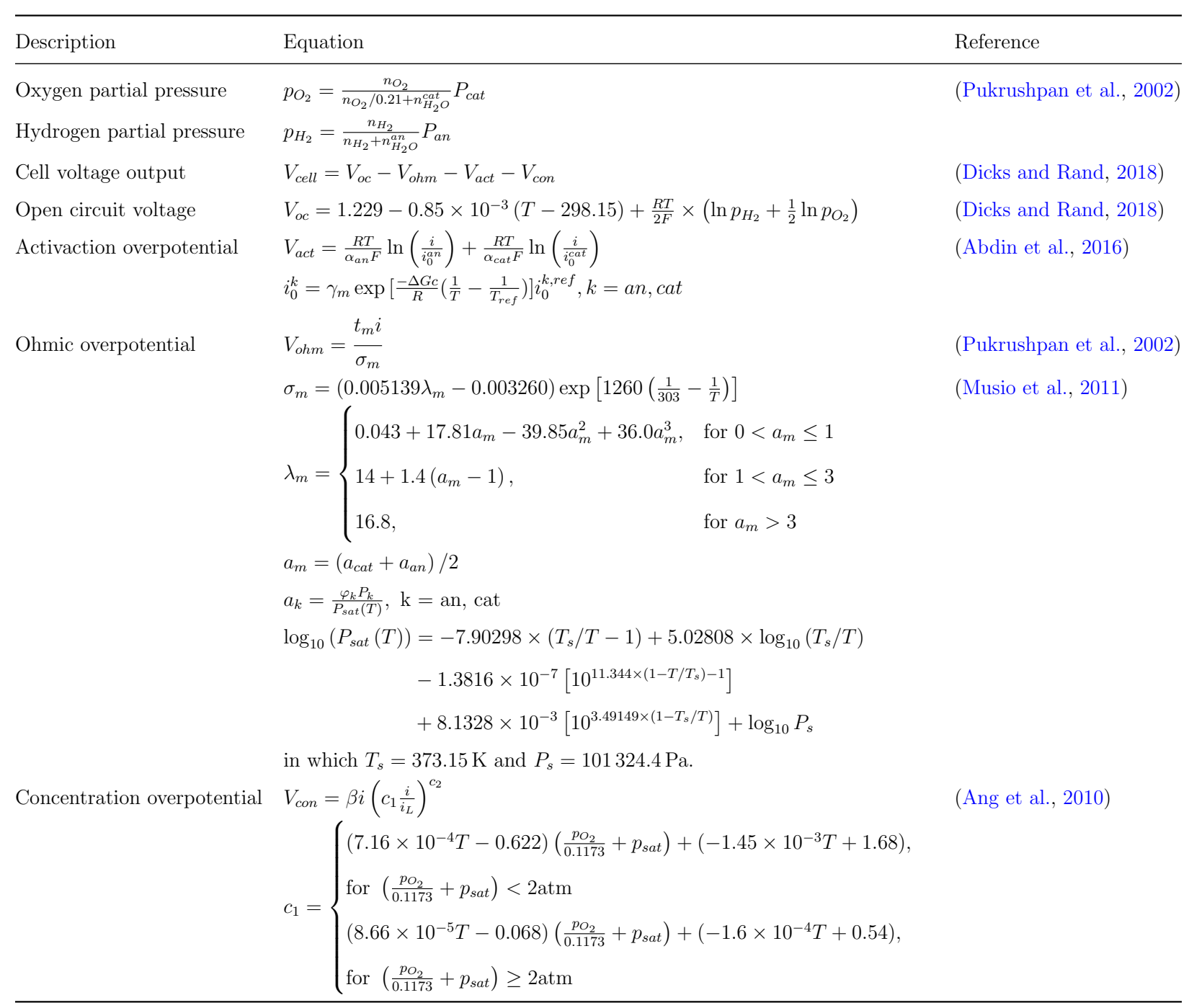

